\title{
Size-resolved aerosol chemistry on Whistler Mountain, Canada with a high-resolution aerosol mass spectrometer during INTEX-B
}

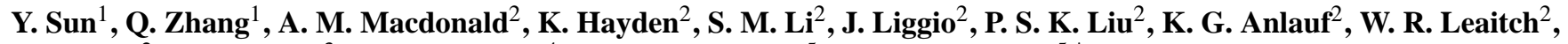 \\ A. Steffen ${ }^{2}$, M. Cubison ${ }^{3}$, D. R. Worsnop ${ }^{4}$, A. van Donkelaar ${ }^{5}$, and R. V. Martin ${ }^{5, *}$ \\ ${ }^{1}$ Atmospheric Sciences Research Center (ASRC), University at Albany, State University of New York, 251 Fuller Road, \\ Albany, NY 12203, USA \\ ${ }^{2}$ Environment Canada, Toronto, Canada \\ ${ }^{3}$ University of Colorado-Boulder, Colorado, USA \\ ${ }^{4}$ Aerodyne Research Inc., Massachusetts, USA \\ ${ }^{5}$ Dalhousie University, Halifax, Canada \\ *also at: Harvard-Smithsonian Center for Astrophysics, Massachusetts, USA
}

Received: 5 September 2008 - Published in Atmos. Chem. Phys. Discuss.: 11 December 2008

Revised: 8 April 2009 - Accepted: 8 May 2009 - Published: 13 May 2009

\begin{abstract}
An Aerodyne High Resolution Time-of-Flight Aerosol Mass Spectrometer (HR-ToF-AMS) was deployed at the peak of Whistler Mountain (2182 $\mathrm{m}$ above sea level), British Columbia, from 19 April to 16 May 2006, as part of the Intercontinental Chemical Transport Experiment Phase $\mathrm{B}$ (INTEX-B) campaign. The mass concentrations and size distributions of non-refractory submicron particle $\left(\mathrm{NR}-\mathrm{PM}_{1}\right)$ species (i.e., sulfate, nitrate, ammonium, chloride, and organics) were measured in situ at 10-min time resolution. The HR-ToF-AMS results agreed well with collocated measurements. The average concentration of non-refractory submicron particulate matter $\left(\mathrm{NR}-\mathrm{PM}_{1} ; 1.9 \mu \mathrm{g} \mathrm{m}^{-3}\right)$ is similar to those observed at other remote, high elevation sites in North America. Episodes of enhanced aerosol loadings were observed, due to influences of regional and trans-Pacific transport of air pollution. Organics and sulfate were the dominant species, on average accounting for $55 \%$ and $30 \%$, respectively, of the NR-PM 1 mass. The average size distributions of sulfate and ammonium both showed an accumulation mode peaking at $\sim 500 \mathrm{~nm}$ in vacuum aerodynamic diameter $\left(D_{v a}\right)$ while those of organic aerosol (OA) and nitrate peaked at $\sim 300 \mathrm{~nm}$. The size differences suggested that sulfate and OA were mostly present in external mixtures from different source origins. We also quantitatively determined the elemental composition of OA using the high resolution mass spectra. Overall, OA at Whistler Peak was highly oxygenated, with an average organic-mass-to-organic-carbon ra-
\end{abstract}

Correspondence to: $\mathrm{Q}$. Zhang

(qz@asrc.cestm.albany.edu) tio $(\mathrm{OM} / \mathrm{OC})$ of $2.28 \pm 0.23$ and an atomic ratio of oxygento-carbon $(\mathrm{O} / \mathrm{C})$ of $0.83 \pm 0.17$. The nominal formula for $\mathrm{OA}$ was $\mathrm{C}_{1} \mathrm{H}_{1.66} \mathrm{~N}_{0.03} \mathrm{O}_{0.83}$ for the entire study. Two significant trans-Pacific dust events originated from Asia were observed at Whistler Peak during this study. While both events were characterized with significant enhancements of coarse mode particles and mineral contents, the composition and characteristics of NR-PM 1 were significantly different between them. One trans-Pacific event occurred on 15 May 2006, during which ammonium sulfate contributed $>90 \%$ of the total NR-PM 1 mass. This event was followed by a high OA episode likely associated with regional emissions. In total, three enhanced regional OA events, each of which lasted 23 days, were observed during this study. In contrast to the two dust events, the regional OA events were generally characterized with higher $\mathrm{OA} /$ sulfate ratio, less oxidized $\mathrm{OA}$, and lower $\mathrm{OM} / \mathrm{OC}$ ratio.

\section{Introduction}

Aerosol particles are an important component of the Earth's atmosphere, playing significant roles in atmospheric chemistry, climate change and public health. Aerosols change the energy balance of the climate system by absorbing and scattering solar radiation and by altering cloud albedo and precipitation. The direct and indirect effects of aerosols on radiative forcing have large uncertainties in both the measurements and modelling of the climate effects of anthropogenic aerosols (IPCC, 2007). 
Rapid industrialization and urbanization in Asia have led to substantial increases of anthropogenic emissions of aerosols and their precursors in the Asian continent (van Aardenne et al., 1999; Streets and Waldhoff, 2000; Carmichael et al., 2002; Streets et al., 2003). Asian emissions can be transported across the Pacific Ocean through midlatitude cyclonic system (Yienger, 2000), affecting air quality and regional climate in North America (Jaffe et al., 1999; Bailey and Barrie, 2000; Jacob et al., 2003; Liang et al., 2004). Due to enhanced frontal activity in eastern Asia and strong atmospheric westerlies, trans-Pacific transport of Asian pollution is most frequent and rapid in spring (Yienger, 2000; Liang et al., 2004). During April and May 2006, the Intercontinental Chemical Transport Experiment, Phase B (INTEX-B) campaign initiated by the National Aeronautics and Space Administration (NASA) was conducted to characterize and quantify the transport and evolution of Asian pollutions to North America and assess its implications for regional air quality and climate (Singh et al., 2006). The INTEX-B campaign involved extensive airborne, satellite, and ground-based measurements of atmospheric composition throughout the North Pacific Ocean and over the west coast of North America, and included a comprehensive suite of gas, aerosol, and remote sensing measurements in Canada (Leaitch et al., 2008; McKendry et al., 2008; van Donkelaar et al., 2008; Singh et al., 2009).

A key component of the Canadian INTEX-B measurement activities was the deployment of a High Resolution Timeof-Flight Aerosol Mass Spectrometer (HR-ToF-AMS; Aerodyne Research Inc.) at the peak of Whistler Mountain from 19 April-16 May 2006. Whistler is a ski resort located approximately $100 \mathrm{~km}$ north of Vancouver in the coast mountain range of British Columbia. Whistler Peak is an ideal site for studying trans-Pacific transport of Asian pollution due to its high elevation ( $2182 \mathrm{~m}$ above sea level) and proximity to the Pacific Ocean. Recent model studies (Heald et al., 2006) and analysis of aircraft observations (van Donkelaar et al., 2008) indicate that trans-Pacific transport of Asian anthropogenic aerosol is most significant in the layer between 700 $900 \mathrm{hPa}$, in which Whistler Peak is located.

AMS has been used widely in field studies of aerosol chemistry and dynamics due to its fast and real-time measurements of the size-resolved chemical compositions of the non-refractory (NR) components in submicron aerosols (e.g., Canagaratna et al., 2007; Zhang et al., 2007a). Most studies by far were done with the Quadrupole-based AMS (QAMS). The application of HR-ToF-AMS for ambient studies has been relatively new and started only in recent years (DeCarlo et al., 2006). Compared to the Q-AMS, the HR-ToFAMS offers significant improvements in both sensitivity of quantification and characterization of organic aerosol (OA) composition (DeCarlo et al., 2006). In particular, the high $\mathrm{m} / \mathrm{z}$ (mass-to-charge ratio) resolution of the HR-ToF-AMS allows the direct determination of elemental composition, i.e., carbon $(\mathrm{C})$, hydrogen $(\mathrm{H})$, nitrogen $(\mathrm{N})$, and oxygen $(\mathrm{O})$, and thus organic-mass-to-organic-carbon ratio (OM/OC) of organic materials (Aiken et al., 2007, 2008).

A main goal of this study is to gain insights into the chemistry, sources, and processes of aerosol particles at Whistler Peak, a site that represents the upper mountain-convective layer (De Wekker et al., 2004) and lower free troposphere in Pacific Northwest, during INTEX-B. We report here the size-resolved chemical composition, concentration, and temporal variations of non-refractory submicron aerosol (NR$\mathrm{PM}_{1}$ ) species (i.e., sulfate, ammonium, nitrate, chloride, and organics) and the inter-comparisons between measurements by the HR-ToF-AMS and those by collocated instruments. The average elemental composition and the atomic ratios of oxygen-to-carbon $(\mathrm{O} / \mathrm{C})$, hydrogen-to-carbon $(\mathrm{H} / \mathrm{C})$, and nitrogen-to-carbon (N/C) for OA are also reported. Finally, a detailed case study is performed on a significant trans-Pacific dust event observed on 15 May 2006 and a regional OA event that immediately followed.

\section{Experimental}

\subsection{Sampling site and time}

This study was performed at Whistler Peak Station $\left(122.95^{\circ} \mathrm{W}, 50.01^{\circ} \mathrm{N}, 2182 \mathrm{~m}\right.$ above sea level) from 19 April-16 May 2006. Further details on the sampling site are given in Leaitch et al. (2008) and McKendry et al. (2008). All dates and times are reported in Pacific Standard Time (PST), which is $8 \mathrm{~h}$ later than Coordinated Universal Time (UTC). Aerosol mass concentrations are reported at ambient pressure, which varied between $\sim 770-790 \mathrm{hPa}$ during this study.

\subsection{HR-ToF-AMS and collocated measurements at Whistler Peak}

\subsubsection{Description of the HR-ToF-AMS}

The HR-ToF-AMS uses the same aerosol sampling, sizing, vaporization and ionization schemes as those of the Q-AMS (Jayne et al., 2000; Jimenez et al., 2003) and the CompactToF-AMS (Drewnick et al., 2005). A detailed description of this instrument is given in DeCarlo et al. (2006). As shown in Fig. 1, aerosol particles are sampled into the HR-ToF-AMS through a $100 \mu \mathrm{m}$ critical orifice mounted at the inlet of an aerodynamic lens (Liu et al., 1995). The lens collimates particles into a narrow beam with near $100 \%$ transmission efficiency for those with vacuum aerodynamic diameter $\left(D_{v a}\right.$, DeCarlo et al., 2004) ranging from 60 to $600 \mathrm{~nm}$ and partial transmissions down to $\sim 30 \mathrm{~nm}$ and up to $\sim 1.5 \mu \mathrm{m}$ in $D_{v a}$ (Jayne et al., 2000; Jimenez et al., 2003; Liu et al., 2007). Note that changes in ambient pressure may lead to changes in particle velocity in the AMS and lens transmission efficiencies (Liu et al., 2007; Bahreini et al., 2008). However, such effects are expected to be small under the air pressure 
at Whistler peak (770-790 hPa) (Liu et al., 2007). The AMS measurements are typically referred to as submicron $\left(\mathrm{PM}_{1}\right)$ since $1 \mu \mathrm{m}$ particles are transmitted at an efficiency of $\sim 50 \%$ (Canagaratna et al., 2007).

At the exit of the aerodynamic lens, particles acquire size-dependant velocities upon supersonic expansion into a high-vacuum $\left(\sim 10^{-5}\right.$ Torr $)$ sizing region. Particles are then directed onto a resistively heated surface (maintained at $\sim 600^{\circ} \mathrm{C}$ during this study) where NR components (e.g., $\mathrm{SO}_{4}^{2-}, \mathrm{NH}_{4}^{+}, \mathrm{NO}_{3}^{-}, \mathrm{Cl}^{-}$, and organic species) are flash vaporized and ionized by $70 \mathrm{eV}$ electron impact. The positively charged ions are then analyzed by a high resolution orthogonal time-of-flight mass spectrometer (TOFWERK, Thun, Switzerland). By placing a spinning chopper (1\% duty cycle) at the entrance of the sizing chamber, the velocities of the particles, and thus their sizes, can be determined based on particle time-of-flight (PToF).

The HR-ToF-AMS operates under two ion optical modes that are referred to as "W-mode" and "V-mode" according to the ion flight trajectories. In V-mode, the mass concentrations and size distributions of aerosol species are quantified at high sensitivity, with detection limits more than 10 times lower than those of the Q-AMS (see Sect. 2.2.3). The Wmode operation, although less sensitive compared to the Vmode due to lower ion throughput, offers a high $\mathrm{m} / \mathrm{z}$ resolution of $\sim 4000-5000$, allowing much improved identification and separation of adjacent ions that are slightly different in exact mass due to differences in elemental composition (DeCarlo et al., 2006). As a result, the W-mode data provide valuable information on the elemental composition and OM/OC ratio of organics (Aiken et al., 2007, 2008).

\subsubsection{HR-ToF-AMS operation and calibrations}

During this study, ambient air was sampled through a stainless steel tube after a cyclone that removes coarse particles at $\sim 2 \mu \mathrm{m}$ size cutoff. The total flow through the stainless steel tube was $10 \mathrm{~L} \mathrm{~min}^{-1}$, out of which $\sim 0.1 \mathrm{~L} \mathrm{~min}^{-1}$ was sampled by the HR-ToF-AMS. The HR-ToF-AMS alternated between the V-mode and the W-mode every 5 min and additionally between the mass spectrum (MS) mode and the PToF mode every $15 \mathrm{~s}$ when it was under the V-mode operation. No PToF data were sampled in the W-mode due to poor signalto-noise $(\mathrm{S} / \mathrm{N})$.

Although the HR-ToF-AMS is sufficiently sensitive to quantify aerosol species at Whistler Peak, the size distribution and high resolution mass spectra (HRMS) data were noisy due to low aerosol loadings (typically at $1-2 \mu \mathrm{g} \mathrm{m}^{-3}$ ). For this reason, a Versatile Aerosol Concentration Enrichment System (VACES) (Geller et al., 2005; Khlystov et al., 2005 ) was operated intermittently (for $27 \%$ of the time during this study) to enhance the S/N of AMS measurements by a factor of $\sim 5.6-7.4$. In this system, particles are first grown to supermicron sizes by water condensation, then concentrated with a virtual impactor, and finally dried prior to

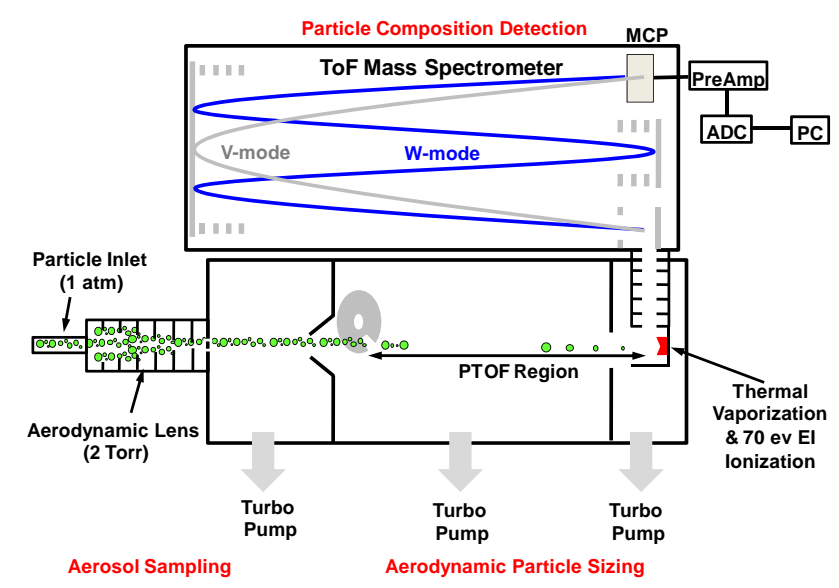

Fig. 1. Schematic of HR-ToF-AMS (Reproduced/modified by permission of American Chemical Society from DeCarlo et al. (2006). Copyright 2006 American Chemical Society.

analysis (Khlystov et al., 2005). This enhancement of S/N is important for the quantitative analysis of the size distribution data and the HRMS. We evaluated the performance of the concentrator by comparing data acquired during runs with the concentrator to those without it. The concentration factors are similar for different species and are consistent to those observed by the Condensation Particle Counter (CPC) measurements. In addition, the normalized mass spectra and the size distributions of sulfate and organics are essentially the same between these two regimes, indicating that the particle concentration processes did not alter aerosol characteristics.

The HR-ToF-AMS was calibrated for inlet flow at the beginning of this study and for ionization efficiency (IE) and particle sizing every $3 \sim 5$ days. The calibration of IE was performed using size-selected, pure ammonium nitrate particles. The measured IE values increased by $\sim 9 \%$ between the first and the second calibrations while the ratio of IE to air beam $(\mathrm{AB})$ signal increased by $\sim 20 \%$. This increase of instrument sensitivity occurred after a pump failure that led to a couple days of instrument down time. The IE/AB ratio remained stable for the rest of study (r.s.d. $<4 \%$, Fig. S1: http://www.atmos-chem-phys.net/9/ 3095/2009/acp-9-3095-2009-supplement.pdf). The particle size calibration was performed using mono-disperse polystyrene latex spheres (PSL; Duke Scientific, Palo Alto, California) with nominal diameters of 100, 150, 269, 350, and $453 \mathrm{~nm}$ respectively and a density of $1.05 \mathrm{~g} \mathrm{~cm}^{-3}$. Detailed protocols for IE and size calibrations are given elsewhere (Jayne et al., 2000; Jimenez et al., 2003; Drewnick et al., 2005). 
Table 1. AMS detection limits $\left(\mathrm{ng} \mathrm{m}^{-3}\right)$ of NR-PM 1 species.

\begin{tabular}{lccccc}
\hline & $\begin{array}{c}\text { HR-ToF-AMS } \\
\text { (This study) }\end{array}$ & \multicolumn{2}{c}{$\begin{array}{c}\text { HR-ToF-AMS } \\
\text { (DeCarlo et al., 2006) }\end{array}$} & $\begin{array}{c}\text { Q-AMS } \\
\text { (Zhang et al., 2005b) }\end{array}$ \\
\cline { 2 - 5 } Organics & Vmode & Wmode & Vmode & Wmode & \\
Sulfate & 26 & 85 & 10 & 160 & 210 \\
Nitrate & 2 & 15 & 2 & 49 & 71 \\
Ammonium & 7 & 64 & 1 & 14 & 14 \\
Chloride & 3 & 9 & 5 & 24 & 160 \\
\hline
\end{tabular}

a Determined as 3 times of the standard deviation of 5-min averaged mass concentration data for particle-free air at Whistler Peak.

b Scaled to 5-min DL.

\subsubsection{HR-ToF-AMS detection limits (DLs)}

The DLs of individual species are determined as 3 times the standard deviations $(3 \sigma)$ of the corresponding signals in particle-free ambient air through a high efficiency particulate air (HEPA) filter (Zhang et al., 2005b). The DLs of organics, $\mathrm{SO}_{4}^{2-}, \mathrm{NO}_{3}^{-}, \mathrm{NH}_{4}^{+}$, and $\mathrm{Cl}^{-}$for the 5-min data are presented in Table 1. The V-mode and W-mode DLs determined for this study are close to the values reported in an earlier study in Riverside, California (DeCarlo et al., 2006). Note that while the W-mode of the HR-ToF-AMS is less sensitive than the V-mode operation, it is more sensitive than the Q-AMS (Zhang et al., 2005b).

\subsubsection{Collocated and nearby measurements}

Relevant measurements at Whistler Peak conducted during this study include: 1) meteorological conditions, e.g., temperature, relative humidity ( $\mathrm{RH})$, and pressure; 2 ) trace gases including $\mathrm{CO}$ (Aerolaser), $\mathrm{O}_{3}$ (TECO 49), and $\mathrm{Hg}$ (Tekran); 3) water-soluble inorganic species $\left(\mathrm{NH}_{4}^{+}, \mathrm{SO}_{4}^{2-}, \mathrm{NO}_{3}^{-}, \mathrm{Cl}^{-}\right.$, $\mathrm{K}^{+}, \mathrm{Ca}^{2+}, \mathrm{Mg}^{2+}$, and $\mathrm{Na}^{+}$) from $24-48 \mathrm{~h}$ filter packs $\left.\left(\sim \mathrm{PM}_{2.0}\right) ; 4\right)$ inorganic and metal ions from Micro-Orifice Uniform Deposit Impactor (MOUDI) operated with 3-stages ( $<1 \mu \mathrm{m}, 1-3 \mu \mathrm{m}$, and $>3 \mu \mathrm{m}) ; 5$ ) particle number distribution by TSI Scanning Mobility Particle Sizer (SMPS, 10$400 \mathrm{~nm}$ ) and Grimm Optical Particle Counter (OPC, Model $1.108,0.3-20 \mu \mathrm{m}$ ); and 6) particle light scattering and absorption by nephelometer and Particle Soot Absorption Photometer (PSAP). Further details on these measurements are given in Leaitch et al. (2008) and McKendry et al. (2008). In addition, vertical profiles of NR-PM 1 species extending from the surface to $\sim 5.5 \mathrm{~km}(\sim 550 \mathrm{hPa})$ near Whistler Peak were sampled twice a day (morning and late afternoon) with a Q-AMS onboard the Canadian Cessna 207 aircraft (Leaitch et al., 2008; McKendry et al., 2008). The 5-min DLs of this Q-AMS were 270 and $18 \mathrm{ng} \mathrm{m}^{-3}$ for organics and $\mathrm{SO}_{4}^{2-}$, respectively (calculated from the 1-min DLs reported in Leaitch et al., 2008).

\subsection{HR-ToF-AMS data processing}

\subsubsection{Standard HR-ToF-AMS data analysis}

Mass concentrations and size distributions of NR-PM species are determined using the standard ToF-AMS Data Analysis Software (SQUIRREL; http://cires.colorado.edu/ jimenez-group/ToFAMSResources/) with IGOR Pro 6.03A (Wavemetrics Inc., Oregon, USA). SQUIRREL employs a user-definable fragmentation table to apportion the total signals into different species (Allan et al., 2004b). Several adjustments in the fragmentation table, such as the air signals at $m / z 16,29$, and 44 , were performed based on the mass spectra of particle-free ambient air. A detailed procedure on fragmentation table adjustment is given in http://cires.colorado.edu/jimenez-group/wiki/index. php/Field_Data_Analysis_Guide. Additional adjustment to the fragmentation table was performed based on HRMS (see Appendix A).

A particle Collection Efficiency (CE) factor of 0.5 is introduced to account for the incomplete detection of NR species due to particle bounce at the vaporizer and/or partial transmission of particles by the lens (Huffman et al., 2005; Salcedo et al., 2007; Matthew et al., 2008). The use of $\mathrm{CE}=0.5$ has been reported in many ambient studies and justified based on extensive inter-comparisons against collocated measurements (Drewnick et al., 2004; Takegawa et al., 2005; Zhang et al., 2005b; Salcedo et al., 2006; Canagaratna et al., 2007). Larger CE values (up to 1) are more appropriate for aerosols more acidic than $\mathrm{NH}_{4} \mathrm{HSO}_{4}$ (Kleinman et al., 2007). The relative ionization efficiency (RIE) values used in this study are 1.4 for organics, 1.2 for sulfate, 1.1 for nitrate and 1.3 for chloride (Jimenez et al., 2003). The RIE $(=4.3)$ for ammonium was measured based on pure $\mathrm{NH}_{4} \mathrm{NO}_{3}$ particles. The concentrator-on data were scaled to the adjacent concentrator-off values based on linear interpretation. Due to problems with the computer control, the concentrator stayed on continuously for $\sim 27 \mathrm{~h}$ from 15 May, 13:35 p.m. to 16 May, 16:55 p.m. Data in this period were adjusted using the average concentration factor. 
The size distributions of sulfate, nitrate, organics and ammonium were determined from the PToF mode of the HR-ToF-AMS. While a complete mass spectrum $(\mathrm{m} / z=10$ $400 \mathrm{amu}$ ) was collected for each PToF size bin, only $\mathrm{m} / \mathrm{z}$ 's with good $\mathrm{S} / \mathrm{N}$ are used to determine the size distributions of individual species since low $\mathrm{S} / \mathrm{N} \mathrm{m} / \mathrm{z}$ 's may introduce overwhelming noise to the size distribution results. The ions chosen for individual species are: $m / z, 16$ for ammonium $\left(\mathrm{NH}_{2}^{+}\right)$; $\mathrm{m} / \mathrm{z} 30$ and 46 for nitrate $\left(\mathrm{NO}^{+}, \mathrm{NO}_{2}^{+}\right) ; \mathrm{m} / z 48$ and 64 for sulfate $\left(\mathrm{SO}^{+}, \mathrm{SO}_{2}^{+}\right)$; and $\mathrm{m} / \mathrm{z} 27,41,42,43,44,55,57,59$, and 60 for organic species.

\subsubsection{High resolution mass spectra (HRMS) analysis}

The W-mode mass spectra are processed using the Peak Integration by Key Analysis (PIKA) software developed in the Jimenez's group at the University of Colorado, Boulder (http://cires.colorado.edu/jimenez-group/ ToFAMSResources/ToFSoftware/PikaInfo/). PIKA employs a peak-shape modified Gaussian fitting algorithm to deconvolve and quantify the signals of a user-defined array of ions (DeCarlo et al., 2006). As the number of possible ions at each integer $\mathrm{m} / \mathrm{z}$ increases with the $\mathrm{m} / \mathrm{z}$ value, the W-mode resolution becomes insufficient to resolve multiplets in the $m / z>100$ regime. Thus only smaller ions $(m / z<100)$ are fitted and used for elemental analysis in this study. This approach should have little effect on the final results as most of the organic signals $(\sim 95 \%)$ appear at $m / z<100$.

The speciated ion signals are first apportioned according to their compositions into air (e.g., $\mathrm{N}_{2}^{+}, \mathrm{O}_{2}^{+}, \mathrm{Ar}^{+}$), ammonium (e.g., $\mathrm{NH}^{+}, \mathrm{NH}_{2}^{+}, \mathrm{NH}_{3}^{+}$), nitrate (e.g., $\mathrm{NO}^{+}$and $\mathrm{NO}_{2}^{+}$), sulfate (e.g., $\mathrm{SO}^{+}, \mathrm{SO}_{2}^{+}$, and $\mathrm{SO}_{3}^{+}$), chloride (e.g., $\mathrm{Cl}^{+}$and $\mathrm{HCl}^{+}$), water (e.g., $\mathrm{H}_{2} \mathrm{O}^{+}, \mathrm{HO}^{+}$, and $\mathrm{O}^{+}$) and organics (the rest of the ions). Ions that may have contributions from more than one species (e.g., $\mathrm{O}^{+}, \mathrm{OH}^{+}, \mathrm{H}_{2} \mathrm{O}^{+}$and $\mathrm{CO}_{2}^{+}$) are deconvolved using the approach discussed in Allan et al. (2004b). Air contributions to $\mathrm{CO}_{2}^{+}$at $m / z 44$ and ${ }^{15} \mathrm{NN}^{+}$at $m / z 29\left({ }^{15} \mathrm{NN}^{+}\right.$and $\mathrm{CHO}^{+}$are not resolvable under the HRToF-AMS resolution) are subtracted based on the ratios of $\mathrm{CO}_{2}^{+} / \mathrm{N}_{2}^{+}$and ${ }^{15} \mathrm{NN}^{+} / \mathrm{N}_{2}^{+}$measured in particle-free ambient air.

The contribution of water vapor to the $\mathrm{H}_{2} \mathrm{O}^{+}$signal at $m / z, 18$ is estimated according to the $\mathrm{H}_{2} \mathrm{O}^{+} / \mathrm{N}_{2}^{+}$ratio in filtered air. The contribution of inorganic sulfate species to $\mathrm{H}_{2} \mathrm{O}^{+}$is estimated according to the known fragmentation patterns of sulfate (Allan et al., 2004b). The rest of the $\mathrm{H}_{2} \mathrm{O}^{+}$ signal is attributed to organic species under the consideration that particles sampled during this study were likely to be dry due to low RH at the AMS inlet (estimated at $<10 \%$ most of the time) because the indoor temperature was typically 20 $30^{\circ} \mathrm{C}$ higher than outside and the sampling line was not thermally insulated.

The organic $\mathrm{H}_{2} \mathrm{O}^{+}$signal determined by subtracting contributions from gaseous and inorganic species, although fairly noisy for being the differences between large values, is generally comparable to that of $\mathrm{CO}_{2}^{+}$during this study. We therefore set $\mathrm{H}_{2} \mathrm{O}^{+}=\mathrm{CO}_{2}^{+}$in the organic fragmentation table and then set $\mathrm{OH}^{+}=25 \% \mathrm{H}_{2} \mathrm{O}^{+}$and $\mathrm{O}^{+}=4 \% \mathrm{H}_{2} \mathrm{O}^{+}$based on the fragmentation pattern of water molecules (Allan et al., 2004b). For Whistler Peak aerosols, 91-99\% (average $=96 \%$ ) of the $m / z 44$ signals were contributed by $\mathrm{CO}_{2}^{+}$ and $\sim 4 \%$ (range: $1.4-9 \%$ ) by other ions, e.g., $\mathrm{C}_{2} \mathrm{H}_{4} \mathrm{O}^{+}$.

Quantification of particulate $\mathrm{CO}^{+}$signal produced from oxygenated organic species is challenging due to the interferences of very large $\mathrm{N}_{2}^{+}$signal from gas phase $\mathrm{N}_{2}$ (Zhang et al., 2005a). Under typical ambient conditions, the intensity of $\mathrm{N}_{2}^{+}$is more than 2 orders of magnitude larger than that of $\mathrm{CO}^{+}$(Zhang et al., 2005a). While the HR-ToF-AMS is in principle capable to quantitatively separate these two ions $\left(m / z=27.9949\right.$ and 28.0061 for $\mathrm{CO}^{+}$and $\mathrm{N}_{2}^{+}$, respectively), the overwhelmingly large $\mathrm{N}_{2}^{+}$signal at $m / z 28$ and the slightly asymmetrical peak-shape may lead to large uncertainties in the $\mathrm{CO}^{+}$mass determined based on the W-mode mass spectra. We are also unable to separate precisely the particulate $\mathrm{CO}^{+}$from the gaseous $\mathrm{N}_{2}^{+}$based on their very different flight velocities in the AMS (Zhang et al., 2005a, b) because of the overwhelming gaseous $\mathrm{N}_{2}^{+}$signals and the noisy particulate signals at $m / z 28$. Since previous studies on ambient aerosols reported $\mathrm{CO}^{+}$to $\mathrm{CO}_{2}^{+}$ratio at $\sim 0.9-1.3$ for ambient OA (Zhang et al., 2005a; Takegawa et al., 2007), we set in this study $\mathrm{CO}^{+}=\mathrm{CO}_{2}^{+}$for OA which is consistent with Aiken et al. (2008).

The ion-speciated mass spectrum is subsequently used to calculate the elemental composition $(\mathrm{C}, \mathrm{H}, \mathrm{O}, \mathrm{N})$ and $\mathrm{OM} / \mathrm{OC}$ ratio of OA (Aiken et al., 2007). The elemental analysis was only performed when OA mass loading was larger than $0.7 \mu \mathrm{g} \mathrm{m}^{-3}$ to reduce noise at low OA concentrations. Ions commonly considered as inorganic are not included in the elemental analysis despite the fact that some of them could be produced by organic species as well, e.g., $\mathrm{NO}^{+}$and $\mathrm{NO}_{2}^{+}$by organic nitrates, $\mathrm{SO}^{+}$and $\mathrm{SO}_{2}^{+}$by organosulfates, and $\mathrm{NH}^{+}, \mathrm{NH}_{2}^{+}$, and $\mathrm{NH}_{3}^{+}$by amino compounds (Sun and Zhang, 2009). Although excluding these ions may potentially lead to a negative bias of $\mathrm{O} / \mathrm{C}, \mathrm{N} / \mathrm{C}$, and $\mathrm{OM} / \mathrm{OC}$ ratios, we see little evidence of the significant presence of such species in aerosols sampled during this study.

\subsection{Air mass trajectory analysis}

Back trajectories reaching Whistler Peak were calculated every $6 \mathrm{~h}$ over the time period of this study using the HYSPLIT 4.8 (Hybrid Single Particle Lagrangian Integrated Trajectories) of National Oceanic and Atmospheric Administration, USA (NOAA) (http://www.arl.noaa.gov/ready/hysplit4. html). The back trajectory analysis was performed with meteorological input from Air Resources Laboratory FNL data archive. More details on HYSPLIT model are given in Draxler and Rolph (2003). 

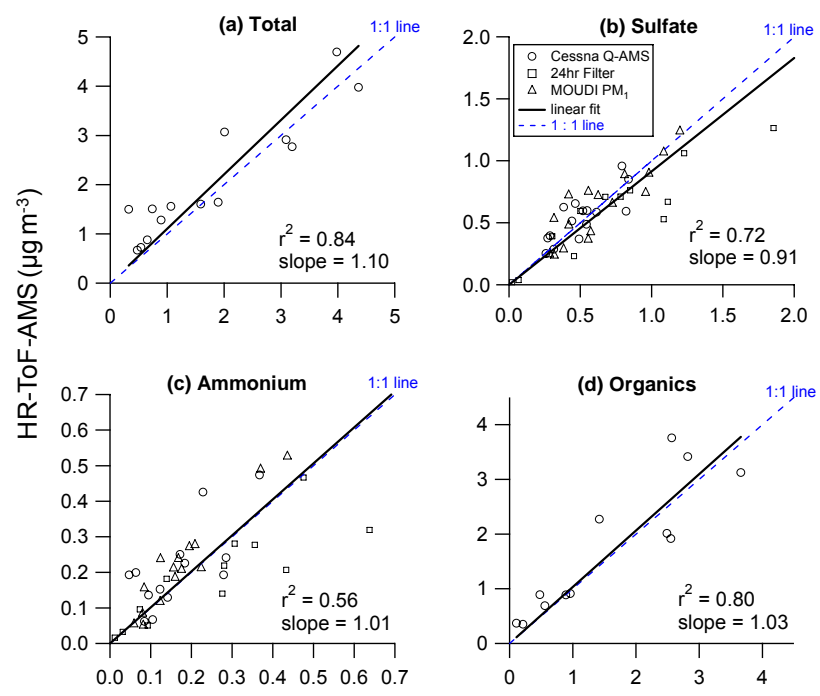

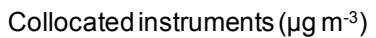

Fig. 2. Comparisons between the HR-ToF-AMS measurements and 24-h averaged filter samples $\left(\sim \mathrm{PM}_{2}\right), 12$-h averaged MOUDI samples $\left(\mathrm{PM}_{1.2}\right)$, and Q-AMS measurements onboard a Cessna 207 aircraft (average of 2100-2300 m a.s.1.) for (a) total NR-PM 1 mass $\left(=\mathrm{SO}_{4}^{2-}+\mathrm{NO}_{3}^{-}+\right.$Organics $\left.+\mathrm{NH}_{4}^{+}+\mathrm{Cl}^{-}\right)$, (b) sulfate, (c) ammonium, and (d) organics.

\section{Results and discussions}

\subsection{Inter-comparisons of collocated measurements}

As shown in Fig. 2a, the total NR-PM 1 mass concentrations determined by the HR-ToF-AMS correlate reasonably well with the average NR-PM ${ }_{1}$ mass concentrations near Whistler Peak Station determined by a Q-AMS on-board a Cessna 207 aircraft (Leaitch et al., 2008). The Q-AMS data correspond to time periods during each upward and downward spiral when the aircraft was located between 2100 $2300 \mathrm{~m}$ (above sea level) near Whistler Peak. The intercomparisons between the mass concentrations of sulfate, ammonium, and organics by the HR-ToF-AMS and those by collocated instruments are shown in Fig. 2b-d. Overall the agreements of these comparisons are fairly good $\left(r^{2}=0.56\right.$ 0.84; slope $=0.91-1.1$ ) given issues such as differences in size cutoff (i.e., $\sim \mathrm{PM}_{1}$ for AMS and MOUDI, and $\sim \mathrm{PM}_{2}$ for 24 $\mathrm{h}$ filters). MOUDI measurements at Whistler Peak indicate that the mass fractions of sulfate and ammonium were significantly enhanced in particles $>1 \mu \mathrm{m}$ during periods influenced by trans-Pacific dust events (Leaitch et al., 2008).

\subsection{Size-resolved aerosol composition and characteristics}

\subsubsection{Temporal variations of NR-PM 1 species}

Figure 3 shows the temporal variations of mass concentrations of organics, sulfate, ammonium, nitrate, chloride as well as meteorological conditions at Whistler Peak during this study. Missing data are due to either hardware/software malfunction or maintenance/calibration of the instrument. The concentration and composition of NR-PM 1 varied dynamically, reflecting influences from multiple sources, processes, regional and trans-Pacific transport, and cloud processing/scavenging.

Organics is the dominant NR-PM 1 component for $\sim 70 \%$ of the time. Three significant $\mathrm{OA}$ accumulation events (marked as OE1, OE2, and OE3 on Fig. 3) were observed and each lasted a few days. Sulfate is usually less abundant than organics in $\mathrm{PM}_{1}$ but episodes of enhanced sulfate were observed. A major sulfate episode occurred on 15 May 2006, during which ammonium sulfates contributed $>90 \%$ of the total NR-PM 1 mass. This episode was identified as one of the two trans-Pacific dust events (marked as DE1 and DE2 on Fig. 3) observed at Whistler Peak during this study (McKendry et al., 2008). A detailed discussion of these events is given in Sect. 3.4.

Nitrate and chloride are generally minor aerosol components. Yet, $\mathrm{NO}_{3}^{-}$increased moderately during some periods, usually accompanied with enhanced OA (Fig. 3). Note that the AMS only measures the more volatile $\mathrm{NH}_{4} \mathrm{NO}_{3}$ and $\mathrm{NH}_{4} \mathrm{Cl}$ and has almost no detection for $\mathrm{NaCl}$ and $\mathrm{NaNO}_{3}$ under its typical heater temperature of $\sim 600^{\circ} \mathrm{C}$. Periods of very low aerosol loadings usually occurred during snowy or foggy conditions (as indicated by near $100 \% \mathrm{RH}$ ), suggesting that cloud scavenging and precipitation play an important role in scavenging aerosols.

The diurnal variation patterns of NR-PM $\mathrm{PM}_{1}$ species, $\mathrm{CO}, \mathrm{O}_{3}, \mathrm{RH}$ and air temperature during this campaign are shown in Fig. S2 in the supplementary material (see http://www.atmos-chem-phys.net/9/3095/2009/ acp-9-3095-2009-supplement.pdf). Neither the NR-PM 1 species nor the gaseous species show pronounced diurnal patterns, indicating that aerosols at Whistler Peak are more strongly influenced by regional and trans-Pacific transport of polluted air masses than by local photochemistry.

\subsubsection{Average composition and size distributions of sub- micron aerosol species}

Figure 4 summarizes the average size-resolved composition of aerosol species over the entire study. The average mass concentrations $( \pm 1 \sigma)$ of organics, sulfate, ammonium, and nitrate are $1.05( \pm 1.03), 0.58( \pm 0.41), 0.23( \pm 0.16)$, and $0.05( \pm 0.10) \mu \mathrm{g} \mathrm{m}^{-3}$, respectively. The average total concentration $\left(=\mathrm{SO}_{4}^{2-}+\mathrm{NO}_{3}^{-}+\mathrm{NH}_{4}^{+}+\mathrm{Cl}^{-}+\right.$Organics $)$of NR-PM 


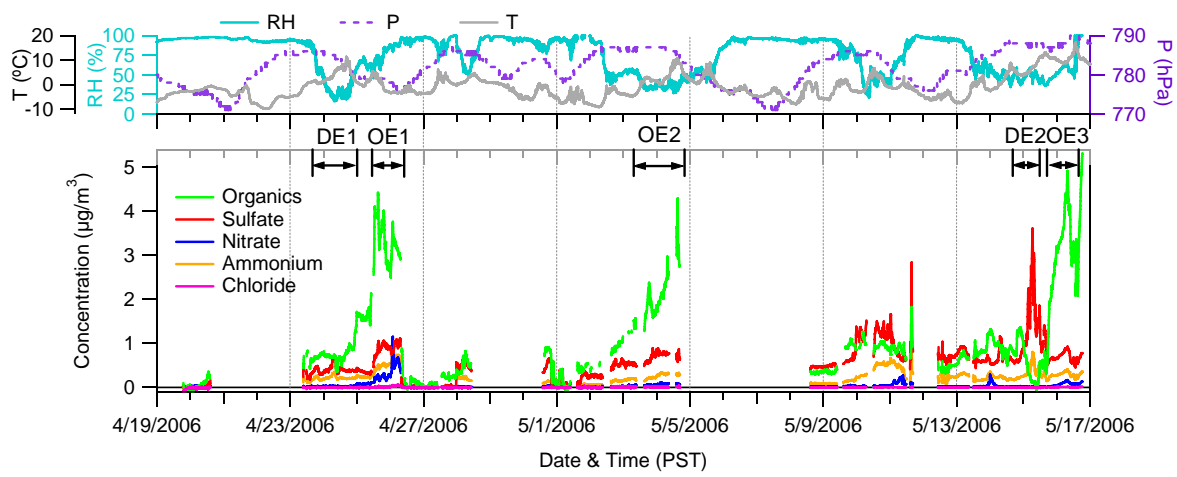

Fig. 3. Time series of the mass concentrations of organics, sulfate, ammonium, nitrate, and chloride in submicron particles at Whistler Peak. Time series of ambient air temperature $(T)$, relative humidity $(\mathrm{RH})$, and pressure $(\mathrm{P})$ are shown in the top panel. Missing data are due to either instrumental/software failure or maintenance/calibrations. Five periods corresponding to two trans-Pacific dust events (DE1 and DE2) and three organic aerosol events (OE1, OE2, and OE3) are marked.

is $1.91 \pm 1.43 \mu \mathrm{g} \mathrm{m}^{-3}$, which is similar to the levels observed at rural/remote sites in Europe and North America (Zhang et al., 2007a). In comparison, the concentrations reported at surface sites at three West Pacific islands (Cheju of Korea, and Okinawa and Fukue of Japan) which are frequently influenced by outflow from China, Korea and Japan, are much higher $\left(\sim 11-13 \mu \mathrm{g} \mathrm{m}^{-3}\right)$, reflecting their geographical closeness to major emission sources in Asia (Takami et al., 2007; Zhang et al., 2007a).

Organics and sulfate are the dominant aerosol species, on average accounting for $55 \%$ and $30 \%$, respectively, of the total NR-PM $\mathrm{PM}_{1}$ mass. Nitrate and chloride typically contribute a small fraction (average $\approx 3 \%$ ) of the NR-PM $\mathrm{PM}_{1}$ mass. These findings are consistent with many observations from rural/remote sites in Northern Hemisphere, except that sulfate is generally more dominant over the remote Pacific and West Pacific (Zhang et al., 2007a).

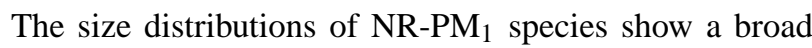
accumulation mode (Fig. 4) that is consistent with a more regional character of NR-PM ${ }_{1}$ at Whistler Peak. Sulfate and ammonium have almost the same size distributions with an accumulation mode peaking around $500 \mathrm{~nm}$ (in $D_{v a}$ ). The larger sulfate and ammonium size modes reflect the association of these two species with aerosols of longer residence time. The dust particles in trans-Pacific events may also have influenced the sulfate size distribution (McKendry et al., 2008).

The size distributions of organics and nitrate are similar to each other and both show a broader distribution that extends to smaller sizes and peaks at $\sim 300 \mathrm{~nm}$. Note that this similarity could be partially due to the influences of organic signals (e.g., $\mathrm{CH}_{2} \mathrm{O}^{+}$and $\mathrm{CH}_{2} \mathrm{O}_{2}^{+}$) on nitrate signals at $\mathrm{m} / \mathrm{z} 30$ $\left(\mathrm{NO}^{+}\right)$and $46\left(\mathrm{NO}_{2}^{+}\right)$(Bae et al., 2007). However, the size distributions of organics and nitrate also tightly correlate during an elevated $\mathrm{NO}_{3}^{-}$event occurred on 25-27 April when $\mathrm{m} / \mathrm{z} 30$ and 46 were almost completely $\mathrm{NO}^{+}$and $\mathrm{NO}_{2}^{+}$(see

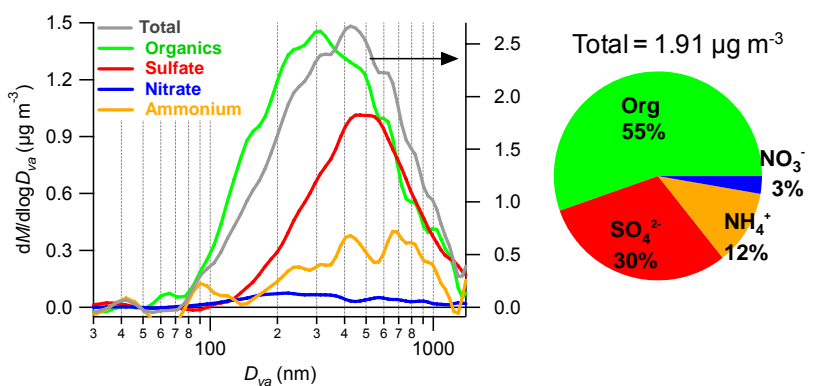

Fig. 4. Average size-resolved chemical composition of $\mathrm{NR}_{-} \mathrm{PM}_{1}$ at Whistler Peak during 19 April-16 May 2006. Total $=\mathrm{SO}_{4}^{2-}+\mathrm{NO}_{3}^{-}+\mathrm{NH}_{4}^{+}+$Organics $+\mathrm{Cl}^{-}$.

Appendix A). These observations, as well as the temporal variation patterns of aerosol species, suggest that Whistler Peak - a representative upper boundary layer/lower free troposphere site for Pacific northwest - is subject to the influences of air masses transported from different source regions, some of which are enriched with OA and to a lesser extent nitrate while others are dominated with aerosols mainly composed of ammonium sulfates.

\subsubsection{Aerosol acidity}

We evaluated the bulk acidity of submicron aerosols using $\mathrm{NH}_{4}^{+}$meas $/ \mathrm{NH}_{4}^{+}$pred, i.e., the ratio of the measured $\mathrm{NH}_{4}^{+}$concentration to the predicted $\mathrm{NH}_{4}^{+}$required to fully neutralize the measured $\mathrm{SO}_{4}^{2-}, \mathrm{NO}_{3}^{-}$, and $\mathrm{Cl}^{-}$(Zhang et al., 2007b). The validity of using this parameter as an aerosol acidity indicator is based on the assumption that the influence of metal ions and organic acids and bases on $\mathrm{NH}_{4}^{+}$meas $/ \mathrm{NH}_{4}^{+}$pred is negligible (Zhang et al., 2007b). While filter measurements of this study indicate that $\mathrm{Na}^{+}, \mathrm{Ca}^{2+}, \mathrm{K}^{+}$, and $\mathrm{Mg}^{2+}$ on 


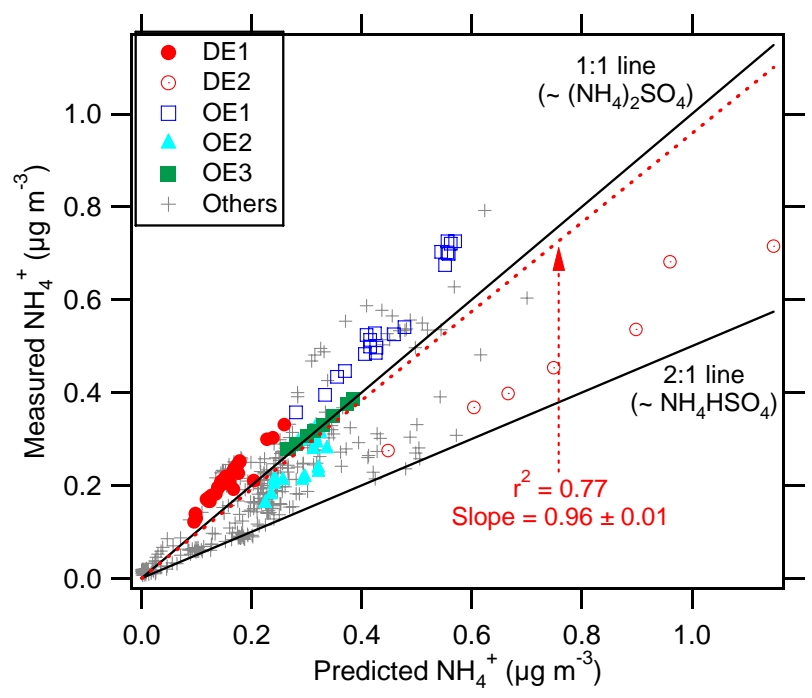

Fig. 5. This scatter plot is a comparison of the mass concentrations of measured vs. predicted $\mathrm{NH}_{4}^{+}$in $\mathrm{PM}_{1}$ at Whistler Peak during 19 April-17 May 2006. The five time periods marked on Fig. 3 are shown in color symbols. The linear fit was performed using an orthogonal distance regression (ODR) model. To reduce noise, all values are 1-h averages.

average account for $\sim 20 \%$ of the total equivalent concentration of cations in $\mathrm{PM}_{2}$, most of them are likely associated with particles larger than $1 \mu \mathrm{m}$ according to MOUDI data (Leaitch et al., 2008). In addition, the influence of metal associated anions on $\mathrm{NH}_{4}^{+}$pred is expected to be small since most metal salts do not evaporate at the typical AMS heater temperature of $600^{\circ} \mathrm{C}$.

The comparison between $\mathrm{NH}_{4}^{+}$meas and $\mathrm{NH}_{4}^{+}$pred of this study (Fig. 5) indicates that the NR-PM 1 at Whistler Peak was bulk neutralized to moderately acidic. The average $\mathrm{NH}_{4}^{+}$meas $/ \mathrm{NH}_{4}^{+}$pred ratio determined by orthogonal distance regression (ODR) to all the data points is $0.96\left(\mathrm{NH}_{4}^{+}{ }_{\text {meas }} / \mathrm{NH}_{4}^{+}\right.$pred $=1$ for $\left.\left(\mathrm{NH}_{4}\right)_{2} \mathrm{SO}_{4}\right)$. More acidic aerosols at $\mathrm{NH}_{4}^{+}$meas $/ \mathrm{NH}_{4}^{+}$pred $<0.9$ were observed, most significantly during 15 May 2006, when Whistler Peak was influenced by a significant trans-Pacific dust event (DE2, Fig. 5). More discussions on this event are given in Sect. 3.5. The hourly averaged $\mathrm{NH}_{4}^{+}$meas $/ \mathrm{NH}_{4}^{+}$pred ratios are always above 0.5 , indicating that submicron aerosols at Whistler Peak were rarely more acidic than $\mathrm{NH}_{4} \mathrm{HSO}_{4}$. Similar level of particle-phase acidity was observed at an urban site - Pittsburgh in US (Zhang et al., 2007b).

Possible reasons for the $\mathrm{NH}_{4}^{+}$meas being slightly higher than the $\mathrm{NH}_{4}^{+}$pred during some time periods include: 1) uncertainties in measurements; 2) the presence of organic acids, which are not included in the calculation of $\mathrm{NH}_{4}^{+}$pred ; and/or 3) overestimation of $\mathrm{NH}_{4}^{+}$meas due to the contributions of organic nitrogen $(\mathrm{ON})$ compounds to $\mathrm{NH}^{+}$and $\mathrm{NH}_{2}^{+}$(Sun

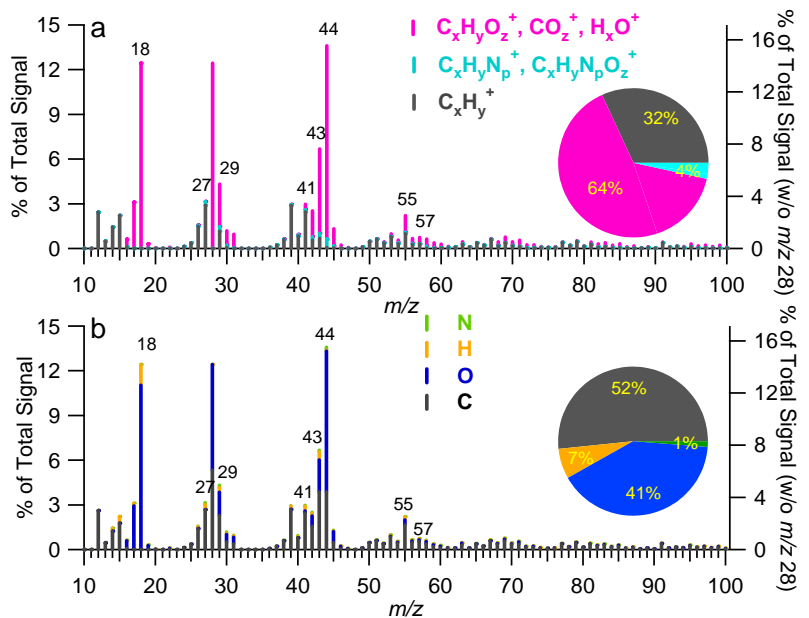

Fig. 6. Average mass spectra of organic aerosols over the entire study, colored with the contribution of (a) ion categories $\left(\mathrm{C}_{\mathrm{x}} \mathrm{H}_{\mathrm{y}}^{+}\right.$, $\left.\mathrm{C}_{\mathrm{x}} \mathrm{H}_{\mathrm{y}} \mathrm{O}_{\mathrm{z}}^{+}, \mathrm{C}_{\mathrm{x}} \mathrm{H}_{\mathrm{y}} \mathrm{N}_{p}^{+}, \mathrm{C}_{\mathrm{x}} \mathrm{H}_{\mathrm{y}} \mathrm{N}_{p} \mathrm{O}_{\mathrm{z}}^{+}, \mathrm{H}_{\mathrm{x}} \mathrm{O}^{+}\right)$and (b) elements $(\mathrm{C}$, $\mathrm{H}, \mathrm{N}$, and $\mathrm{O}$ ). The left axes show the percent contribution of each peak to the total signal using the revised fragmentation table, i.e., with $m / z, 28\left(\mathrm{CO}^{+}=\mathrm{CO}_{2}^{+}\right)$. The right axes indicate the percentage of each peak using the standard AMS fragmentation table (Allan et al., 2004b), i.e., without $m / z 28\left(\mathrm{CO}^{+}=0\right)$. The pie charts summarize the average composition of $\mathrm{OA}$ in terms of ion categories and elements, respectively.

and Zhang, 2009). The detection of ON species is evident in the HRMS (e.g., Fig. A1a), however, the contributions of organic-related $\mathrm{NH}_{\mathrm{x}}^{+}$ions to $\mathrm{NH}_{4}^{+}$meas concentration are expected to be low given the low concentrations of N-containing organic ions (i.e., $\mathrm{C}_{\mathrm{x}} \mathrm{H}_{\mathrm{y}} \mathrm{N}_{p}^{+}, \mathrm{C}_{\mathrm{x}} \mathrm{H}_{\mathrm{y}} \mathrm{N}_{p} \mathrm{O}_{\mathrm{z}}^{+}$) detected in Whistler aerosols. Yet, it is possible that organic acids played a role to the observation of excessive $\mathrm{NH}_{4}^{+}$meas since higher $\mathrm{NH}_{4}^{+}$meas $/ \mathrm{NH}_{4}^{+}$pred was generally observed in association with higher OA mass and elevated $\mathrm{O} / \mathrm{C}$ ratio. $m / z 44 / \mathrm{OA}$ ratio, which is a surrogate for $\mathrm{O} / \mathrm{C}$ ratio (Aiken et al., 2008), has been found to correlate well with the mass concentrations of organic acids in ambient aerosol (Takegawa et al., 2007).

\subsection{Organic aerosol characteristics and elemental com- position}

Figure 6 shows the average mass spectrum of OA for the entire study, colored coded according to ion categories (i.e., $\mathrm{C}_{\mathrm{x}} \mathrm{H}_{\mathrm{y}}^{+}, \mathrm{C}_{\mathrm{x}} \mathrm{H}_{\mathrm{y}} \mathrm{N}_{p}^{+}, \mathrm{C}_{\mathrm{x}} \mathrm{H}_{\mathrm{y}} \mathrm{N}_{p} \mathrm{O}_{\mathrm{z}}^{+}, \mathrm{C}_{\mathrm{x}} \mathrm{H}_{\mathrm{y}} \mathrm{O}_{\mathrm{z}}^{+}$, and $\mathrm{H}_{\mathrm{x}} \mathrm{O}^{+}$; Fig. 6a) and elements (i.e., C, H, O, and N; Fig. 6b). The $m / z 44$ peak is almost completely $\mathrm{CO}_{2}^{+}$and represents one of the largest peaks in the spectrum. The dominant $m / z 44$ peak is characteristic for the mass spectra of aged, highly oxidized particulate organics (Alfarra et al., 2004; Zhang et al., 2005a). The $m / z 57$ peak, which has been recognized as a mass spectral signature for fossil fuel combustion related hydrocarbonlike OA (HOA) (Zhang et al., 2005c), is only a small peak, 

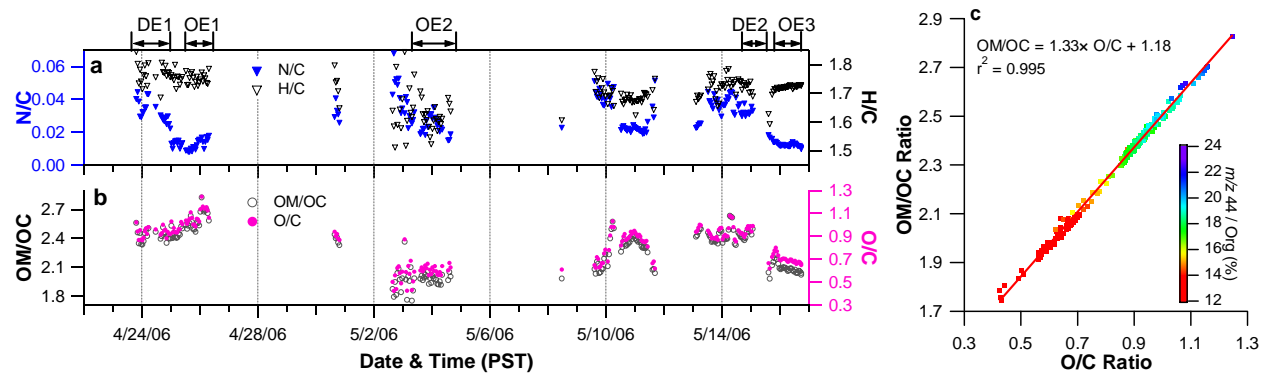

Fig. 7. Time series of 1-hour averaged (a) N/C and $\mathrm{H} / \mathrm{C}$ and (b) $\mathrm{OM} / \mathrm{OC}$ and $\mathrm{O} / \mathrm{C}$ ratios of NR-PM $\mathrm{M}_{1}$ sampled at Whistler Peak. The correlation of $\mathrm{OM} / \mathrm{OC}$ vs. $\mathrm{O} / \mathrm{C}$ ratios is shown in (c) to the right. Only ratios determined with good $\mathrm{S} / \mathrm{N}\left(\mathrm{i} . \mathrm{e}\right.$., organics $>0.7 \mu \mathrm{g} \mathrm{m}{ }^{-3}$ ) are shown.

of which only $50 \%$ of the signal was contributed by $\mathrm{C}_{4} \mathrm{H}_{9}^{+}$ (the rest by $\mathrm{C}_{3} \mathrm{H}_{5} \mathrm{O}^{+}$). As illustrated in the pie chart on Fig. 6a, OA sampled at Whistler Peak are highly oxidized with oxygen-containing ions (i.e., $\mathrm{C}_{\mathrm{x}} \mathrm{H}_{\mathrm{y}} \mathrm{O}_{\mathrm{z}}^{+}$and $\mathrm{H}_{\mathrm{x}} \mathrm{O}^{+}$) on average accounting for $64 \%$ of the total signal in OA spectrum. Hydrocarbon ions $\left(\mathrm{C}_{\mathrm{x}} \mathrm{H}_{\mathrm{y}}^{+}\right)$are responsible for an average $32 \%$ of the total spectral signal while the rest $4 \%$ of the total is contributed by nitrogen-containing ions $\mathrm{C}_{\mathrm{x}} \mathrm{H}_{\mathrm{y}} \mathrm{N}_{p}^{+}$and $\mathrm{C}_{\mathrm{x}} \mathrm{H}_{\mathrm{y}} \mathrm{N}_{p} \mathrm{O}_{\mathrm{z}}^{+}$.

Figure 7 shows the time series of $\mathrm{OM} / \mathrm{OC}, \mathrm{H} / \mathrm{C}, \mathrm{O} / \mathrm{C}$, and $\mathrm{N} / \mathrm{C}$ ratios determined for Whistler OA. To minimize noises, ratios reported are $1 \mathrm{~h}$ averages and only for OA concentrations larger than $0.7 \mu \mathrm{g} \mathrm{m}^{-3}$. The reported atomic ratios are corrected by the calibration factors given in Aiken et al. (2008), i.e., 0.75 for O/C, 0.91 for H/C, and 0.96 for N/C. The OM/OC ratio varies from 1.75 to 2.83 with the average $( \pm 1 \sigma)$ being $2.28( \pm 0.23)$. This value is close to the $2.1 \pm 0.2$ suggested for rural/remote aerosols by Turpin and Lim (2001) and the OM/OC ratios determined for the highly oxidized OA in urban outflow and the oxygenated OA (OOA) components derived via multivariate factor analysis of ambient OA spectra (Zhang et al., 2005c; Aiken et al., 2008).

The $\mathrm{O} / \mathrm{C}$ atomic ratio ranges between 0.43 and 1.25 with an average value of $0.83( \pm 0.17)$. The average $\mathrm{H} / \mathrm{C}$ and $\mathrm{N} / \mathrm{C}$ are $1.66( \pm 0.06)$ and $0.027( \pm 0.012)$, respectively. Based on the elemental composition of individual $\mathrm{m} / \mathrm{z}$ fragments (Fig. 6b), we determined the nominal formula for Whistler $\mathrm{OA}$ as $\mathrm{C}_{1} \mathrm{H}_{1.66} \mathrm{~N}_{0.03} \mathrm{O}_{0.83}$. The OM/OC ratio correlates tightly with $\mathrm{O} / \mathrm{C}\left(r^{2}=0.995\right.$, Fig. $\left.7 \mathrm{c}\right)$, largely due to low mass contributions from $\mathrm{H}$ and $\mathrm{N}$. In addition, the ratio of $\mathrm{m} / \mathrm{z} 44$ to total OA signal (i.e., $m / z 44 \%$ ), which has been used as an indicator for OA oxidation, also correlates well with $\mathrm{O} / \mathrm{C}$ $\left(r^{2}=0.92\right.$; Fig. 8). The relationships among $\mathrm{O} / \mathrm{C}, \mathrm{m} / \mathrm{z} 44 \%$, and $\mathrm{OM} / \mathrm{OC}$ for Whistler $\mathrm{OA}$ are determined as:

$\mathrm{O} / \mathrm{C}=0.0479 \times m / z 44 \%+0.0658$

$\mathrm{OM} / \mathrm{OC}=1.33 \times \mathrm{O} / \mathrm{C}+1.18$

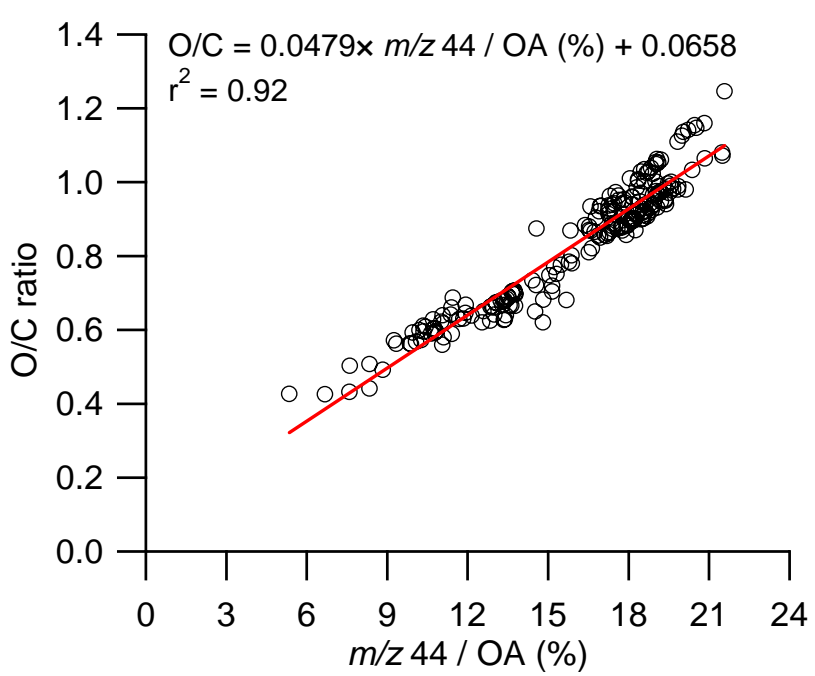

Fig. 8. The correlation of 1 -h averaged $\mathrm{O} / \mathrm{C}$ ratio vs. $m / z 44$ to organics ratio (in percentage) determined from the $\mathrm{W}$-mode mass spectra.

These equations could be useful for deriving $\mathrm{O} / \mathrm{C}$ and $\mathrm{OM} / \mathrm{OC}$ ratios for rural/remote $\mathrm{OA}$ using data acquired with the low mass resolution Q-AMS and C-ToF-AMS. Note that Eqs. (1) and (2) show a slightly higher slope for $\mathrm{O} / \mathrm{C}$ vs. $\mathrm{m} / \mathrm{z} 44 \%$ and $\mathrm{OM} / \mathrm{OC}$ vs. O/C than those reported for Mexico City OA (Aiken et al., 2008). These differences could be related to the estimation of organic water signals as the Aiken et al. (2008) study set $\mathrm{H}_{2} \mathrm{O}^{+}=0.225 \mathrm{CO}_{2}^{+}$while in this study we set $\mathrm{H}_{2} \mathrm{O}^{+}=\mathrm{CO}_{2}^{+}$(see Sect. 2.3.2).

Previous studies reported the observation of significant amounts of organic nitrogen species such as amino acids, urea, organic nitrates and amines in atmospheric aerosols (Cornell et al., 2001; Zhang et al., 2002; Wolfe et al., 2007). The frequent detection of $\mathrm{CH}_{4} \mathrm{~N}^{+}$(Fig. A1) and $\mathrm{CHN}^{+}$ions indeed indicates the presence of $\mathrm{ON}$ in Whistler aerosol. We determined that $\mathrm{N}$ atom on average contributes $\sim 1 \%$ of the total $\mathrm{OA}$ mass and the average $\mathrm{N} / \mathrm{C}$ and $\mathrm{OM} / \mathrm{ON}$ ratios are 


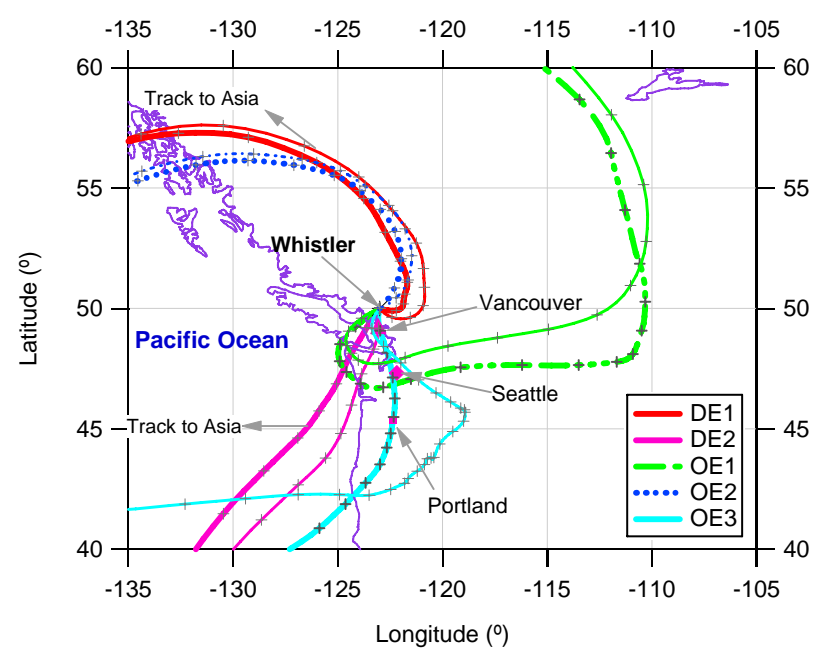

Fig. 9. HYSPLIT back trajectories for the two dust events (i.e., DE1 and DE2 marked on Fig. 3) and three organic aerosol events (i.e., OE1, OE2, and OE3) observed at Whistler Peak (2182 m). In total, 5-8 trajectories were obtained for each event, but only two representative trajectories are shown for each event for the sake of clarity. Check marks are shown at 4-h intervals.

$0.03( \pm 0.01)$ and $96( \pm 52)$, respectively. The N/C ratio in this study is close to those observed for OA in Mexico City (Aiken et al., 2007) but much lower than those in fog waters collected from Central Valley, California where ON is abundant in aerosol particles and precipitation due to agricultural activities (Zhang and Anastasio, 2001; Sun and Zhang, 2009).

\subsection{Characteristics of aerosols associated with different events}

Two significant dust events (DE1 and DE2) and three enhanced OA events (OE1, OE2, and OE3) marked on Fig. 3 were observed during this study. The dust events DE1 and DE2 occurred between 23 April, 09:30 and 24 April, 22:15 and during 15 May, 03:15-09:30, respectively. The two dust events were both followed by substantial enhancement of OA, i.e., OE1 (25 April, 12:00-26 April, 07:20) and OE3 (15 May, 23:45-16 May, 07:45). Another organic event OE2 was observed during 3 May, 15:30 to 4 May, 16:40. Back trajectory analysis suggests different sources and transport pathways of the air masses arriving at Whistler Peak during these events (Fig. 9). The air masses of DE1 and DE2 both originated in continental Asia, but arrived at Whistler Peak from north and south, respectively, after $\sim 1$ week over the Pacific Ocean (McKendry et al., 2008; van Donkelaar et al., 2008). The air masses of OE1 and OE3 originated from the north and south respectively, and both passed through the Vancouver urban region to the south before arriving at Whistler Peak. Another difference between OE1 and OE3 is

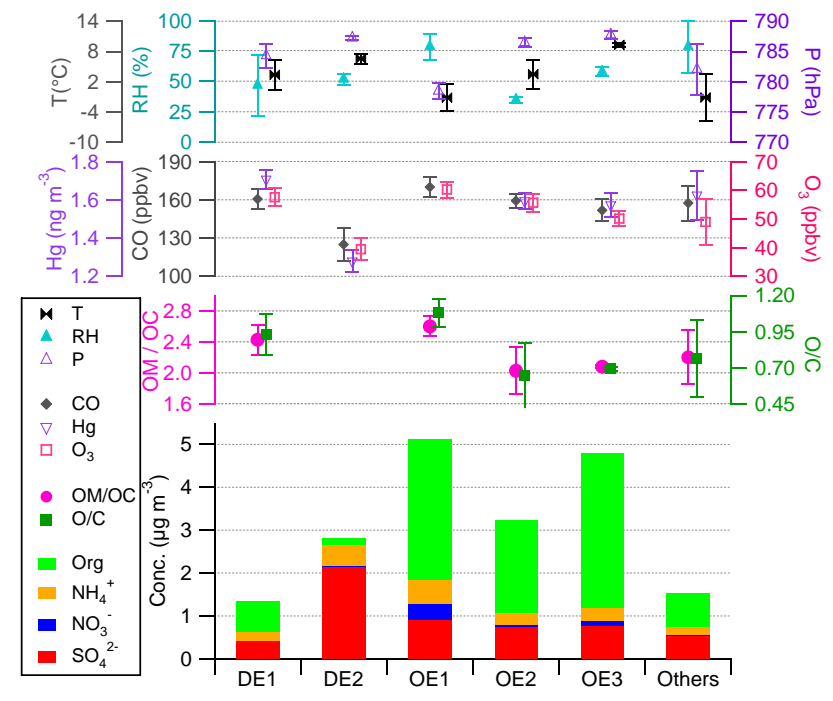

Fig. 10. The average mass concentrations of NR-PM 1 species, the mixing ratios of $\mathrm{CO}, \mathrm{O}_{3}$ and $\mathrm{Hg}$, meteorological conditions, as well as the ratios of $\mathrm{OM} / \mathrm{OC}$ and $\mathrm{O} / \mathrm{C}$ during the two dust events (i.e., DE1 and DE2), three organic aerosol events (i.e., OE1, OE2, and OE3), and the rest of the time periods (i.e., Others). The time periods for each event are marked on Fig. 3. The error bar shows one standard deviation $(1 \sigma)$ of the measurement for each event.

that the air mass of OE1 spent $\sim 1-2$ days over the Pacific Ocean before reaching Whistler Peak while the air mass of OE3 arrived at Whistler Peak from the north.

The different origins and transport pathways appear to have played an important role in controlling the aerosol composition and processes at Whistler Peak. The average mass loadings of NR-PM 1 during the three enhanced OA events range between 3.23 and $5.14 \mu \mathrm{g} \mathrm{m}^{-3}$, significantly higher than those during the dust events $\left(1.33\right.$ and $2.83 \mu \mathrm{g} \mathrm{m}^{-3}$ for DE1 and DE2, respectively; Fig. 10). Organics contributes $64-75 \%$ of the total NR-PM 1 during the enhanced OA events while sulfate accounts for a higher fraction during the two dust events $(30 \%$ and $76 \%$ for DE1 and DE2, respectively). OA at Whistler is likely contributed by regional sources including biogenic SOA from tree emissions, while sulfate is mainly driven by trans-Pacific transport in addition to a regional-related background, similar to the findings reported in previous studies (Brock et al., 2004; Peltier et al., 2008). The aerosol measurements by an HR-ToF-AMS onboard the C-130 aircraft during INTEX-B also indicate that trans-Pacific Asian pollution is associated with sulfatedominated aerosol (Dunlea et al., 2008). Although nitrate is overall a minor $\mathrm{PM}_{1}$ component during this study, higher fraction of nitrate was observed during the $\mathrm{OE}$ events, especially during OE1 (Fig. 10). Nitrate is almost completely depleted in $\mathrm{PM}_{1}$ associated with the dust events. These results further support the regional characteristics for the OEs since ammonium nitrate particles are easily scavenged during 
long range transport. One of the possible reasons that $\mathrm{OE} 1$ shows the highest fraction of nitrate is the low ambient temperature (Fig. 10) which favors the partition of gaseous $\mathrm{NH}_{3}$ and $\mathrm{HNO}_{3}$ to particle phase $\mathrm{NH}_{4} \mathrm{NO}_{3}$ (Seinfeld and Pandis, 2006). For time periods excluding the five identified events (termed as "Others" in Fig. 10), the average mass concentration $\left(1.54 \mu \mathrm{g} \mathrm{m}^{-3}\right)$ and composition (52\% organics, $34 \%$ sulfate, and $12 \%$ ammonium) of NR-PM 1 are similar to those for the entire study (Fig. 4).

The mixing ratios of gas phase pollutants $\left(\mathrm{CO}, \mathrm{O}_{3}\right.$, and $\mathrm{Hg}$ ) are similar among DE1 and the three OE events (CO: 152-170 ppb; $\mathrm{O}_{3}$ : 49-58 ppb; and $\mathrm{Hg}: 1.57-1.71 \mathrm{ng} \mathrm{m}^{-3}$; Fig. 10). Trace gas mixing ratios are much lower during DE2, suggesting different source origins of DE1 and DE2, as well as possibly different emphases on atmospheric processes during the trans-Pacific transport. Sulfate and $\mathrm{CO}$ are well correlated $\left(r^{2}=0.79\right.$; Fig. $\left.11 \mathrm{a}\right)$ in the case of DE2, but there is almost no correlation in the case of DE1 $\left(r^{2}=0.01\right.$; Fig. 11b). In contrast, the OE events show good correlations between OA and $\mathrm{CO}$ (e.g., $r^{2}=0.74$ for OE3 and $r^{2}=0.48$ for $\mathrm{OE} 1$; Fig. 11c) and between $\mathrm{OA}$ and $\mathrm{O}_{3}$ (e.g., $r^{2}=0.68$ for OE2 and $r^{2}=0.95$ for OE3; Fig. 11d), suggesting that OA at Whistler Peak are mostly associated with regional urban pollution to the south and biogenic emissions from the Whistler valley and surrounding areas.

The average $( \pm 1 \sigma) \mathrm{OM} / \mathrm{OC}$ and $\mathrm{O} / \mathrm{C}$ ratios for $\mathrm{OA}$ in $\mathrm{DE} 1$ are $2.43( \pm 0.19)$ and $0.93( \pm 0.14)$, respectively, indicating that OA in DE1 is highly oxidized. These ratios are close to those of highly aged, oxygenated OA component determined with component analysis (Aiken et al., 2008). The nominal formula of OA determined for DE1 is $\mathrm{C}_{1} \mathrm{H}_{1.71} \mathrm{~N}_{0.032} \mathrm{O}_{0.93}$. Although the $\mathrm{OM} / \mathrm{OC}$ and $\mathrm{O} / \mathrm{C}$ ratios in $\mathrm{DE} 2$ are not reported due to very low OA concentrations and thus large uncertainties with elemental analysis, they are likely to be high in DE2 given the long aging processes during transport. Indeed, as shown in Fig. 15c, the OA mass spectrum of DE2 is very similar to that of fulvic acid-a surrogate for highly aged, oxidized OA (Zhang et al., 2005a). Our observations are consistent with those by Dunlea et al. (2008), who reported high O/C ratio of $\mathrm{OA}$ in highly aged Asian pollution layer observed from the C-130 aircraft during INTEXT-B.

$\mathrm{OA}$ is highly oxidized during $\mathrm{OE} 1$ with $\mathrm{O} / \mathrm{C}$ ratio of 1.08 . The nominal formula of OA determined for this event is $\mathrm{C}_{1} \mathrm{H}_{1.70} \mathrm{~N}_{0.013} \mathrm{O}_{1.08}$, showing the highest degree of oxidation among all events. The average mixing ratio of $\mathrm{O}_{3}$ during OE1 is also the highest among those of all events, at $60.2 \pm 2.7$ ppbV (Fig. 10). According to back trajectory analysis, the air mass of OE1 spent $\sim 1-2$ days over the Pacific Ocean before reaching Whistler Peak (Fig. 9), which is consistent with the OA being highly aged. In addition, given the relatively high relative humidity $(78.2 \pm 10.5 \%$, Fig. 10$)$ of ambient air during this event, aqueous phase processing might also have played a role in oxidizing the organics.
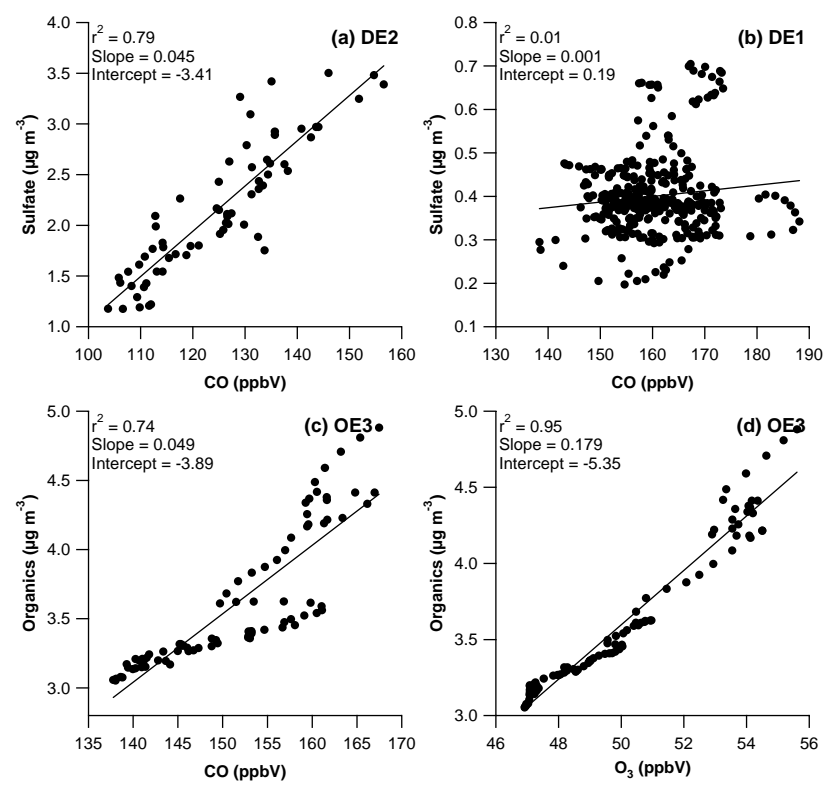

Fig. 11. Scatter plots of (a) $\mathrm{SO}_{4}^{2-}$ vs. $\mathrm{CO}$ in $\mathrm{DE} 2$, (b) $\mathrm{SO}_{4}^{2-}$ vs. $\mathrm{CO}$ in DE1, (c) Organics vs. $\mathrm{CO}$ in $\mathrm{OE} 3$, (d) Organics vs. $\mathrm{O}_{3}$ in $\mathrm{OE} 3$.

The average $\mathrm{O} / \mathrm{C}$ ratios for $\mathrm{OA}$ during $\mathrm{OE} 2$ and $\mathrm{OE} 3$ are 0.65 and 0.69 , respectively, which are close to those determined for "fresher" SOA components in ambient aerosol (Aiken et al., 2008), but higher than the $\mathrm{O} / \mathrm{C}$ ratio in SOA $\left(\mathrm{C}_{1} \mathrm{H}_{1.32} \mathrm{O}_{0.48}\right)$ produced from dark ozonolysis of $\alpha$-pinene under low OA mass loading condition $\left(0.1 \mu \mathrm{g} \mathrm{m}^{-3}\right)$ (Shilling et al., 2009). The nominal formulas of OA for OE2 and OE3 are $\mathrm{C}_{1} \mathrm{H}_{1.58} \mathrm{~N}_{0.023} \mathrm{O}_{0.65}$, and $\mathrm{C}_{1} \mathrm{H}_{1.67} \mathrm{~N}_{0.012} \mathrm{O}_{0.69}$, respectively. It is interesting to point out that although the air mass trajectories of OE2 and OE3 trace back to different source regions (Fig. 9), the OA of these two events show quite similar bulk elemental compositions. These results indicate that $\mathrm{OA}$ in $\mathrm{OE} 2$ and $\mathrm{OE} 3$ are relatively fresher and less processed in comparison to those sampled during OE1, perhaps representative of the oxidation products of regional biogenic emissions. In addition, the nominal formulas of $\mathrm{OA}$ also suggest higher $\mathrm{N}$ contents and $\mathrm{N} / \mathrm{C}$ ratios in DEs than OEs (e.g., N/C ratio=0.032 (DE1), 0.013 (OE1), 0.023 $(\mathrm{OE} 2)$ and $0.012(\mathrm{OE} 3))$. These results are consistent with the observations at Mount Bachelor Observatory during INTEX$\mathrm{B}$ that the trans-Pacific transport of Asian pollution leads to a substantial increase of $\mathrm{N}$-containing organic compounds acyl peroxy nitrates (Wolfe et al., 2007). More discussions on DE2 and OE3 are given in the following section.

\subsection{A case study of sulfate to organic transition at Whistler}

One prominent sulfate event (i.e., DE2) occurred at $\sim 03: 00$ a.m. on 15 May and reached a peak concentration of $\sim 3.6 \mu \mathrm{g} \mathrm{m}^{-3}$ at 06:30 a.m. in association with a modest 


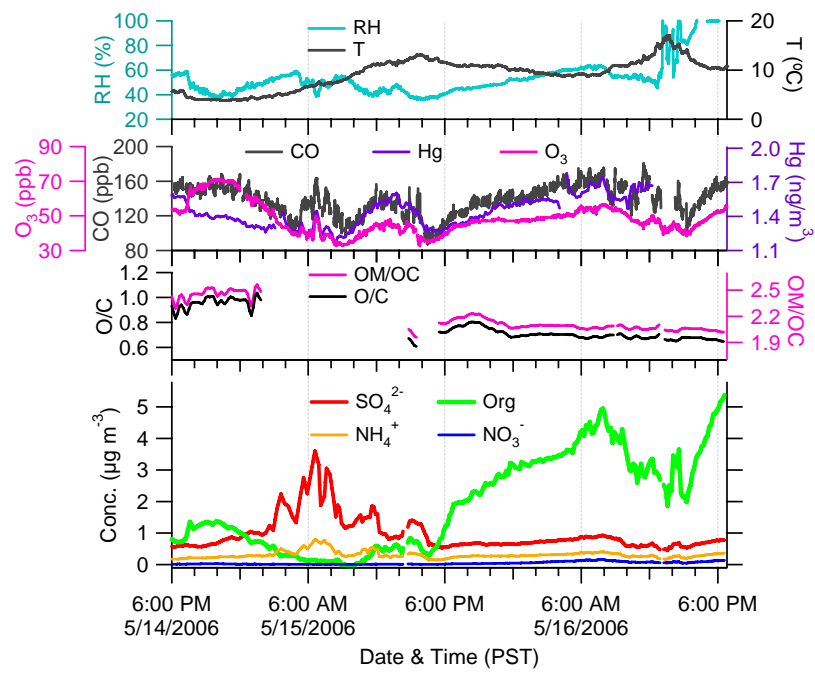

Fig. 12. Time series of mass concentrations of NR-PM $\mathrm{P}_{1}$ species, the mixing ratios of $\mathrm{CO}, \mathrm{O}_{3}$ and $\mathrm{Hg}$, meteorological conditions, as well as the ratios of $\mathrm{OM} / \mathrm{OC}$ and $\mathrm{O} / \mathrm{C}$ during the high sulfate to high organic transition period on 15-16 May.

increase of gas phase pollutants $\left(\mathrm{Hg}, \mathrm{CO}\right.$, and $\left.\mathrm{O}_{3}\right)$ and a decrease of OA concentration to $<0.10 \mu \mathrm{g} \mathrm{m}^{-3}$ (Fig. 12). This enhanced sulfate event was identified as one of the two significant trans-Pacific dust events observed at Whistler Peak during this study (McKendry et al., 2008). Figure 13 shows the vertical distribution of simulated East Asian sulfate from the GEOS-Chem chemical transport model (http:// www-as.harvard.edu/chemistry/trop/geos/) at Whistler Peak Station over 13-16 May. Simulation data was generated using GEOS-Chem v7-04-09, modified as described by van Donkelaar et al. (2008) to contain updated local and East Asian emissions representative of the INTEX-B period. Simulation results are consistent with a trans-Pacific event and show an elevated East Asian plume arriving over Whistler Peak on 14 May, subsiding around 15 May and dissipating by 16 May. In addition, vertical profiles of aerosol loading and atmospheric chemistry measured by a Raman LIDAR system provide further support to the trans-Pacific transport nature of this event (McKendry et al., 2008).

The elevated sulfate event lasted for $\sim 0.5$ day and was followed by a transition of air masses at $\sim 04: 00$ p.m. with a synchronous increase of OA and gas phase pollutants till the end of the study. During DE2, NR-PM 1 is composed primarily of ammonium (18\%) and sulfate (76\%) and are relatively acidic (Fig. 5). In contrast, during the subsequent OA event (i.e., OE3) NR-PM 1 is composed of $77 \%$ organics and is bulk neutralized (Fig. 5). The size distributions shown in Fig. 14 indicate that sulfate and the much lower OA during DE2 are mainly associated with larger particles (peaking at $\sim 600 \mathrm{~nm}$ ). In contrast, particles appear to be more externally mixed during OE3, containing a smaller mode of organics/nitrate (peaking at $\sim 250 \mathrm{~nm}$ ) and a larger mode of sulfate.

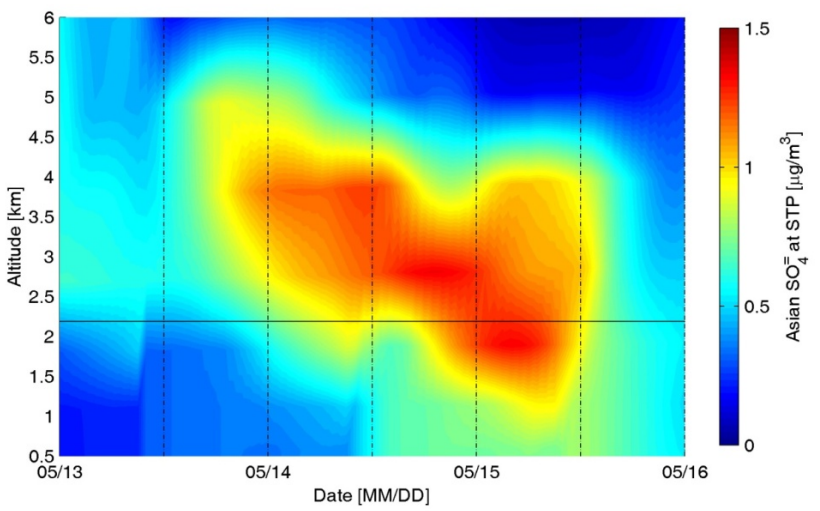

Fig. 13. Simulated East Asian sulfate between $123.75-121.25^{\circ} \mathrm{W}$ and $49-51^{\circ} \mathrm{N}$. The black horizontal line corresponds to the altitude of Whistler Peak Station. Standard temperature and pressure (STP) is treated as $25^{\circ} \mathrm{C}$ and $1 \mathrm{~atm}$.

(a)

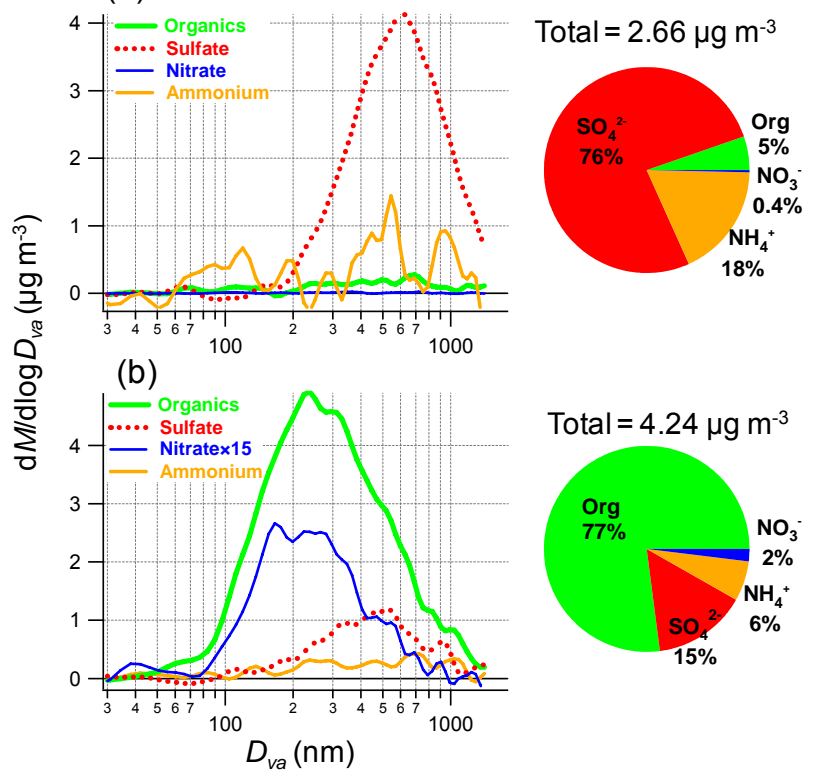

Fig. 14. Averaged size distributions and chemical composition of NR species during (a) the sulfate event (i.e., DE2) and (b) the organic event (i.e., OE3).

The size distribution of sulfate is similar to that observed during DE2. The smaller sizes of organics/nitrate aerosols suggest that they are generally less chemically aged than sulfate aerosols.

Figure 15 shows the average HRMS of OA during OE3 colored by the organic ion categories and elements, respectively. OA is largely oxygenated with an average $\mathrm{O} / \mathrm{C}$ ratio of 0.69 , but not as chemically aged as those observed during the other periods (Fig. 10). During OE3, the contribution from $\mathrm{C}_{\mathrm{x}} \mathrm{H}_{\mathrm{y}} \mathrm{O}_{\mathrm{z}}^{+}$to total OA signal is lower $(60 \%)$ and the $\mathrm{OM} / \mathrm{OC}$ and $\mathrm{O} / \mathrm{C}$ ratios are smaller (Sect. 3.4 and Fig. 10). 

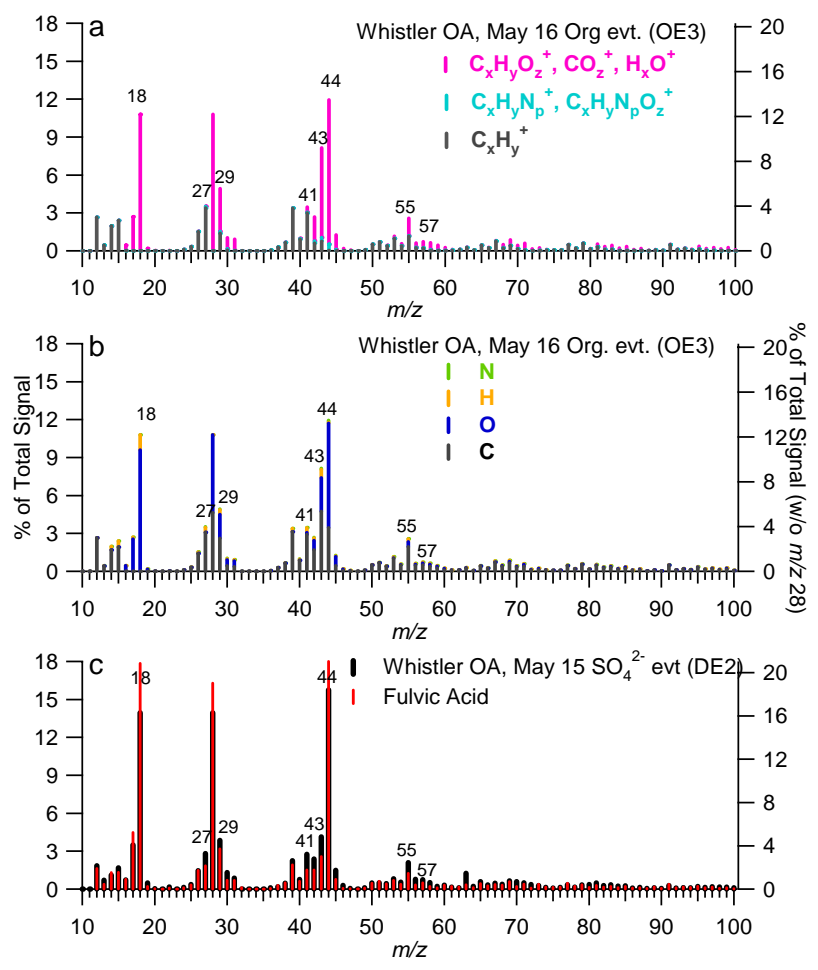

Fig. 15. Average high resolution mass spectrum of $\mathrm{OA}$ during OE3 colored by (a) ion categories $\left(\mathrm{C}_{\mathrm{x}} \mathrm{H}_{\mathrm{y}}^{+}, \mathrm{C}_{\mathrm{x}} \mathrm{H}_{\mathrm{y}} \mathrm{O}_{\mathrm{z}}^{+}, \mathrm{C}_{\mathrm{x}} \mathrm{H}_{\mathrm{y}} \mathrm{N}_{p}^{+}\right.$, $\mathrm{C}_{\mathrm{x}} \mathrm{H}_{\mathrm{y}} \mathrm{N}_{p} \mathrm{O}_{\mathrm{Z}}^{+}, \mathrm{H}_{\mathrm{x}} \mathrm{O}^{+}$) and (b) elements $(\mathrm{C}, \mathrm{H}, \mathrm{N}$, and $\mathrm{O}$ ). (c) Average mass spectrum of OA sampled during DE2 and in comparison, the mass spectrum of fulvic acid (Sun and Zhang, 2009). The left axes show the percent contribution of each peak to the total signal using the revised fragmentation table, i.e., with $\mathrm{m} / \mathrm{z} 28$ $\left(\mathrm{CO}^{+}=\mathrm{CO}_{2}^{+}\right)$. The right axes indicate the percentage of each peak using the standard AMS fragmentation table (Allan et al., 2004b), i.e., without $m / z 28\left(\mathrm{CO}^{+}=0\right)$.

The OA mass spectrum of DE2 shows high similarity with the HRMS of fulvic acid (Fig. 15c) (Sun and Zhang, 2009), indicating that $\mathrm{OA}$ in DE2 is highly aged. The time series of $\mathrm{OM} / \mathrm{OC}$ and $\mathrm{O} / \mathrm{C}$ during the transition period (Fig. 12) also show obvious decreasing trends (e.g., from $\mathrm{OM} / \mathrm{OC}=\sim 2.4$ and $\mathrm{O} / \mathrm{C}=\sim 1.0$ before $\mathrm{DE} 2$ to $\mathrm{OM} / \mathrm{OC}=\sim 2.0$ and $\mathrm{O} / \mathrm{C}=\sim 0.7$ during OE3). This observation is consistent with the hypotheses that the OA observed in DE2 are mainly associated with highly aged air masses that had endured trans-Pacific transport and that the OA of OE3 are mainly associated with relatively fresh, regional air masses originated in the Whistler Valley and to the south (see Sect. 3.4).

\section{Conclusions}

The mass concentrations and chemically-speciated size distributions of submicron particles were characterized in situ with an Aerodyne HR-ToF-AMS deployed at the peak of
Whistler Mountain in spring 2006 during INTEX-B. The high mass resolution spectra allowed the determination of the elemental composition of most small ion fragments $(m / z<100 \mathrm{amu})$, and subsequently the OM/OC, O/C, H/C, and $\mathrm{N} / \mathrm{C}$ ratios for $\mathrm{OA}$.

The concentration, composition and size distributions of NR-PM 1 varied dynamically at Whistler Peak, reflecting influences from regional and trans-Pacific transport, as well as cloud processing and scavenging. Organic and sulfate aerosols prevailed at Whistler, on average accounting for $55 \%$ and $30 \%$, respectively, of the total NR-PM 1 mass. Sulfate and ammonium appeared to be internally mixed with a large accumulation mode peaking around $500 \mathrm{~nm}$ in $D_{v a}$. The average size distributions of OA and nitrate both peaked at $\sim 300 \mathrm{~nm}$. In addition, OA at Whistler was composed almost entirely of OOA with average OM/OC and O/C ratios of 2.28 and 0.83 , respectively.

Two trans-Pacific dust events of Asian origins and three regional OA events were observed during this study. Compared to the elevated OA events, the trans-Pacific dust events were generally characterized with relatively lower mass concentration of NR-PM 1 , higher sulfate-to-OA ratio, and more aged and oxidized OA with higher OM/OC and O/C ratios. The dust event that occurred on 15 May showed elevated sulfate aerosol that persisted for $\sim 0.5$ day. During this dust/sulfate episode, aerosols appeared to be an internal mixture of sulfate and ammonium, which accounted for $>90 \%$ of the NR-PM 1 mass and showed a large accumulation mode that peaked at $\sim 600 \mathrm{~nm}$. This event was followed by a large enhancement of OA event, during which aerosols appeared to be more externally mixed with a smaller mode $(\sim 200 \mathrm{~nm})$ consisting of OA and nitrate and a larger mode composed of sulfate that was likely the residue of the dust/sulfate event. Analyses of OA mass spectra, back-trajectories, and aircraft vertical profiles suggested that the enhancement of OA mass during this event was likely due to regional plumes, including urban pollution transported from the south and secondary aerosols produced from biogenic emissions in the Whistler valley and surrounding regions.

\section{Appendix A}

\section{Improvement of speciation based on HRMS analysis}

Nitrate concentrations determined based on AMS measurements can be significantly overestimated, especially for aerosols sampled at rural/remote locations (Allan et al., 2004a; Bae et al., 2007; Cottrell et al., 2008). Bae et al. (2007) suggested that the biases are due to interference from organic signals at the major $\mathrm{m} / \mathrm{z}$ 's of inorganic nitrate (i.e., $m / z$ 30), based on Q-AMS and Particle-into-liquidsystem coupled with Ion Chromatography (PILS-IC) data acquired from a rural site in New York. The high resolution 

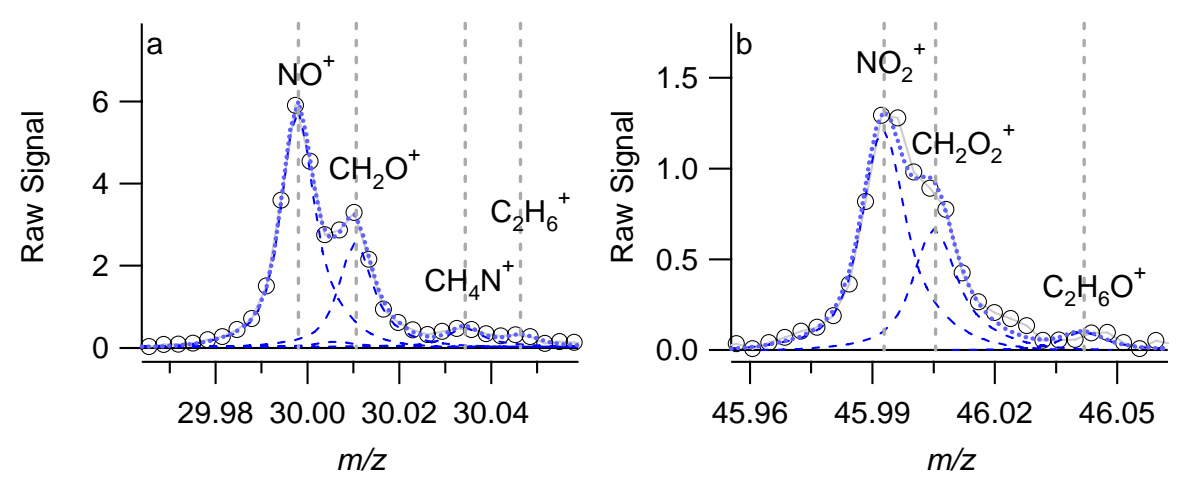

Fig. A1. An example of the high resolution raw mass spectra that show the presence of oxygenated and/or nitrogen-containing organic aerosol signals at (a) $\mathrm{m} / \mathrm{z} 30$ and (b) $\mathrm{m} / \mathrm{z}$ 46. The gray open circles are the W-mode data. The blue curves are the PIKA fits.
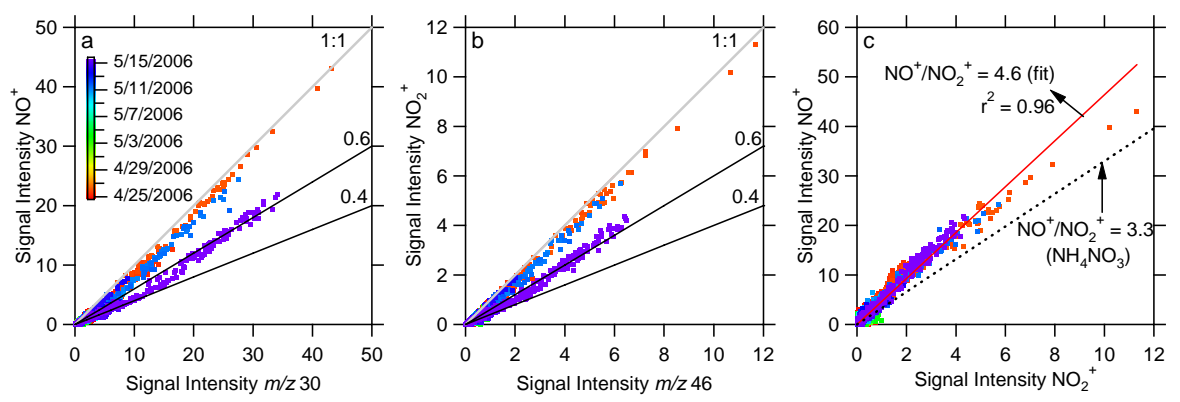

Fig. A2. Scatter plots of (a) $\mathrm{NO}^{+}$vs. $m / z$ 30; (b) $\mathrm{NO}_{2}^{+}$vs. $m / z 46$; and (c) $\mathrm{NO}^{+}$vs. $\mathrm{NO}_{2}^{+}$. Data points are colored by the time. The red line on $\mathrm{c}$ is the fit line of orthogonal distance regression (ODR).

capability of the HR-ToF-AMS allows a direct examination of such interferences. For example, Fig. A1 clearly shows the presence of organic ions $\mathrm{CH}_{2} \mathrm{O}^{+}$and $\mathrm{CH}_{4} \mathrm{~N}^{+}$at $\mathrm{m} / z 30$ and $\mathrm{CH}_{2} \mathrm{O}_{2}^{+}$and at $m / z$ 46. Other organic ions, e.g., $\mathrm{C}_{2} \mathrm{H}_{6}^{+}$at $\mathrm{m} / z 30$ and $\mathrm{C}_{2} \mathrm{H}_{6} \mathrm{O}^{+}$at $\mathrm{m} / z$ 46, are less abundant in aerosols sampled at Whistler Peak, although they have been observed at significant quantities during other studies (Sun and Zhang, 2009).

As shown in Fig. A2 the ratios of $\mathrm{NO}^{+}$to $m / z 30$ and $\mathrm{NO}_{2}^{+}$ to $m / z 46$ ranges from $0.4-1.0$, indicating that organic species contribute up to $\sim 60 \%$ of the $\mathrm{m} / \mathrm{z}, 30$ and 46 signals during this study. We therefore modified the fragmentation table of nitrate using the ratios of $\mathrm{NO}^{+} / \mathrm{m} / z 30$ and $\mathrm{NO}_{2}^{+} / \mathrm{m} / z 46$ determined based on the $\mathrm{W}$-mode data. Without this correction, the nitrate concentrations may be overestimated by $\sim 20-50 \%$. Note that Bae et al. (2007) suggested $m / z 46$ as a "purer" peak for nitrate and proposed to estimate nitrate concentration in rural/remote aerosols on the basis of this peak and the $m / z 30$ to $m / z 46$ ratio determined from pure $\mathrm{NH}_{4} \mathrm{NO}_{3}$. While their PILS-IC vs. AMS comparison seemed to support this approach, this study indicates that $\mathrm{m} / \mathrm{z} 46$ may not be completely $\mathrm{NO}_{2}^{+}$either for ambient aerosols.
The $\mathrm{NO}^{+}$and $\mathrm{NO}_{2}^{+}$signals correlate tightly during this study with an average ratio of 4.6 (Fig. A2c). This value is higher than the $\mathrm{NO}^{+} / \mathrm{NO}_{2}^{+}$ratio (=3.3) determined for ammonium nitrate, suggesting potential influences from organic nitrates and/or mineral nitrates such as $\mathrm{NaNO}_{3}$ (e.g., Allan et al., 2004a; Sun and Zhang, 2009). The good correlation $\left(r^{2}=0.74\right)$ between $\mathrm{NO}_{3}^{-}$and $\mathrm{Na}^{+}$in $\mathrm{PM}_{2}$ according to filter measurements might support the significant presence of mineral nitrate although the effect is expected to be limited since the typical AMS vaporizer is not hot enough to vaporize metal salts. While we are unable to decide the importance of organic nitrates, the low quantities of $\mathrm{N}$-containing ions detected (see Sect. 3.3) suggest that organic nitrates might not be a significant contributor to submicron aerosols at Whistler Peak.

The same approach can be applied to remove the interferences of organic signals to the major ions of sulfate as well, such $m / z 48\left(\mathrm{SO}^{+}\right.$and $\left.\mathrm{C}_{4}^{+}\right)$and $m / z 64\left(\mathrm{SO}_{2}^{+}, \mathrm{C}_{4} \mathrm{O}^{+}\right.$, and $\mathrm{C}_{5} \mathrm{H}_{4}^{+}$). However, since for this study both $\mathrm{m} / z 48$ and 64 are almost purely $\mathrm{SO}^{+}$and $\mathrm{SO}_{2}^{+}$, respectively, with negligible contributions from organic signals, the concentration of sulfate was determined with the standard analysis approach. 
Acknowledgements. This research was supported by University at Albany, State University of New York, through Qi Zhang's Startup Fund and the National Sciences and Engineering Research Council of Canada and Environment Canada. We thank Jose-Luis Jimenez (University of Colorado at Boulder (CU)) for lending us the particle concentrator, Donna Sueper (CU), James Allan (U. Manchester, UK), Peter DeCarlo (CU), Allison Aiken (CU), and Edward Dunlea (CU) for the SQUIRREL and the PIKA AMS data analysis software. Armand Gaudenzi, Dave Halpin and John Deary provided technical and logistical support. Special thanks to Juniper Buller, Anton Horvath, the Whistler Ski Patrol and Whistler Blackcomb for their support.

Edited by: T. Hoffmann

\section{References}

Aiken, A. C., DeCarlo, P. F., and Jimenez, J. L.: Elemental analysis of organic species with electron ionization high-resolution mass spectrometry, Anal. Chem., 79, 8350-8358, 2007.

Aiken, A. C., DeCarlo, P. F., Kroll, J. H., Worsnop, D. R., Huffman, J. A., Docherty, K. S., Ulbrich, I. M., Mohr, C., Kimmel, J. R., Sueper, D., Sun, Y., Zhang, Q., Trimborn, A., Northway, M., Ziemann, P. J., Canagaratna, M. R., Onasch, T. B., Alfarra, M. R., Prevot, A. S. H., Dommen, J., Duplissy, J., Metzger, A., Baltensperger, U., and Jimenez, J. L.: O/C and OM/OC ratios of primary, secondary, and ambient organic aerosols with HighResolution Time-of-Flight Aerosol Mass Spectrometry, Environ. Sci. Technol., 42, 4478-4485, 2008.

Alfarra, M. R., Coe, H., Allan, J. D., Bower, K. N., Boudries, H., Canagaratna, M. R., Jimenez, J. L., Jayne, J. T., Garforth, A., Li, S.-M., and Worsnop, D. R.: Characterization of urban and regional organic aerosols in the Lower Fraser Valley using two Aerodyne Aerosol Mass Spectrometers, Atmos. Environ., 38, 5745-5758, 2004.

Allan, J. D., Bower, K. N., Coe, H., Boudries, H., Jayne, J. T., Canagaratna, M. R., Millet, D. B., Goldstein, A. H., Quinn, P. K., Weber, R. J., and Worsnop, D. R.: Submicron aerosol composition at Trinidad Head, California, during ITCT 2K2: Its relationship with gas phase volatile organic carbon and assessment of instrument performance, J. Geophys. Res.-Atmos., 109, D23S24, doi: 10.1029/2003JD004208, 2004a.

Allan, J. D., Delia, A. E., Coe, H., Bower, K. N., Alfarra, M. R., Jimenez, J. L., Middlebrook, A. M., Drewnick, F., Onasch, T. B., Canagaratna, M. R., Jayne, J. T., and Worsnop, D. R.: A generalised method for the extraction of chemically resolved mass spectra from Aerodyne aerosol mass spectrometer data, J. Aerosol Sci., 35, 909-922, 2004b.

Bae, M. S., Schwab, J. J., Zhang, Q., Hogrefe, O., Demerjian, K. L., Weimer, S., Rhoads, K., Orsini, D., Venkatachari, P., and Hopke, P. K.: Interference of organic signals in highly time resolved nitrate measurements by low mass resolution aerosol mass spectrometry, J. Geophys. Res.-Atmos., 112, D22305, doi:22310.21029/22007JD008614, 2007.

Bahreini, R., Dunlea, E. J., Matthew, B. M., Simons, C., Docherty, K. S., DeCarlo, P. F., Jimenez, J. L., Brock, C. A., and Middlebrook, A. M.: Design and Operation of a Pressure-Controlled Inlet for Airborne Sampling with an Aerodynamic Aerosol Lens, Aerosol Sci. Tech., 42, 465-471, 2008.
Bailey, R. and Barrie, L.: Atmospheric organochlorine pesticides in the western Canadian Arctic-Evidence of transpacific transport, J. Geophys. Res., 105, 11805-11811, 2000.

Brock, C. A., Hudson, P. K., Lovejoy, E. R., Sullivan, A., Nowak, J. B., Huey, L. G., Cooper, O. R., Cziczo, D. J., de Gouw, J., Fehsenfeld, F. C., Holloway, J. S., Hubler, G., Lafleur, B. G., Murphy, D. M., Neuman, J. A., Nicks, D. K., Orsini, D. A., Parrish, D. D., Ryerson, T. B., Tanner, D. J., Warneke, C., Weber, R. J., and Wilson, J. C.: Particle characteristics following cloudmodified transport from Asia to North America, J. Geophys. Res, 109, D23S26, doi:10.1029/2003JD004198, 2004.

Canagaratna, M., Jayne, J., Jimenez, J. L., Allan, J. A., Alfarra, R., Zhang, Q., Onasch, T., Drewnick, F., Coe, H., Middlebrook, A., Delia, A., Williams, L., Trimborn, A., Northway, M., Kolb, C., Davidovits, P., and Worsnop, D.: Chemical and Microphysical Characterization of Aerosols via Aerosol Mass Spectrometry, Mass Spectrom. Rev., 26, 185-222, 2007.

Carmichael, G. R., Streets, D. G., Calori, G., Amann, M., Jacobson, M. Z., Hansen, J., and Ueda, H.: Changing Trends in Sulfur Emissions in Asia: Implications for Acid Deposition, Air Pollution, and Climate, Environ. Sci. Technol., 36, 4707-4713, 2002.

Cornell, S., Mace, K., Coeppicus, S., Duce, R., Huebert, B., Jickells, T., and Zhuang, L. Z.: Organic nitrogen in Hawaiian rain and aerosol, J. Geophys. Res, 106, 7973-7983, 2001.

Cottrell, L. D., Griffin, R. J., Jimenez, J. L., Zhang, Q., Ulbrich, I., Ziemba, L. D., Beckman, P. J., Sive, B. C., and Talbot, R. W.: Submicron particles at Thompson Farm during ICARTT measured using aerosol mass spectrometry, J. Geophys. Res, 113, D08212, doi:08210.01029/02007JD009192, 2008.

De Wekker, S. F. J., Steyn, D. G., and Nyeki, S.: A Comparison Of Aerosol-Layer And Convective Boundary-Layer Structure Over A Mountain Range During Staaarte'97, Bound.-Lay. Meteorol., 113, 249-271, 2004.

DeCarlo, P., Slowik, J. G., Worsnop, D. R., Davidovits, P., and Jimenez, J. L.: Particle morphology and density characterization by combined mobility and aerodynamic diameter measurements. Part 1: Theory, Aerosol Sci. Tech., 38, 1185-1205, 2004.

DeCarlo, P. F., Kimmel, J. R., Trimborn, A., Northway, M. J., Jayne, J. T., Aiken, A. C., Gonin, M., Fuhrer, K., Horvath, T., Docherty, K. S., Worsnop, D. R., and Jimenez, J. L.: Field-Deployable, High-Resolution, Time-of-Flight Aerosol Mass Spectrometer, Anal. Chem., 78, 8281-8289, 2006.

Draxler, R. R. and Rolph, G. D.: HYSPLIT (HYbrid Single-Particle Lagrangian Integrated Trajectory) Model access via NOAA ARL READY Website (http://www.arl.noaa.gov/ready/hysplit4.html), NOAA Air Resources Laboratory, Silver Spring, MD, USA, 2003.

Drewnick, F., Schwab, J. J., Jayne, J. T., Canagaratna, M., Worsnop, D. R., and Demerjian, K. L.: Measurement of ambient aerosol composition during the PMTACS-NY 2001 using an Aerosol Mass Spectrometer. Part I: Mass concentrations, Aerosol Sci. Tech., 38, 92-103, 2004.

Drewnick, F., Hings, S. S., DeCarlo, P. F., Jayne, J. T., Gonin, M., Fuhrer, K., Weimer, S., Jimenez, J. L., Demerjian, K. L., Borrmann, S., and Worsnop, D. R.: A new Time-of-Flight Aerosol Mass Spectrometer (ToF-AMS) - Instrument description and first field deployment, Aerosol Sci. Tech., 39, 637-658, 2005.

Dunlea, E. J., DeCarlo, P. F., Aiken, A. C., Kimmel, J. R., Peltier, R. E., Weber, R. J., Tomlison, J., Collins, D. R., Shinozuka, 
Y., McNaughton, C. S., Howell, S. G., Clarke, A. D., Emmons, L. K., Apel, E. C., Pfister, G. G., van Donkelaar, A., Martin, R. V., Millet, D. B., Heald, C. L., and Jimenez, J. L.: Evolution of Asian aerosols during transpacific transport in INTEX-B, Atmos. Chem. Phys. Discuss., 8, 15375-15461, 2008, http://www.atmos-chem-phys-discuss.net/8/15375/2008/.

Geller, M. D., Biswas, S., Fine, P. A., and Sioutas, C.: A new compact aerosol concentrator for use in conjunction with low flow-rate continuous aerosol instrumentation, J. Aerosol Sci., 36, 1006-1022, 2005.

Heald, C. L., Jacob, D. J., Park, R. J., Alexander, B., Fairlie, T. D., Yantosca, R. M., and Chu, D. A.: Transpacific transport of Asian anthropogenic aerosols and its impact on surface air quality in the United States, J. Geophys. Res., 111, D14310, doi:14310.11029/12005JD006847, 2006.

Huffman, J. A., Jayne, J. T., Drewnick, F., Aiken, A. C., Onasch, T., Worsnop, D. R., and Jimenez, J. L.: Design, modeling, optimization, and experimental tests of a particle beam width probe for the Aerodyne Aerosol Mass Spectrometer, Aerosol Sci. Tech., 39, 1143-1163, 2005.

IPCC: Summary for Policymakers, in: Climate Change 2007: The Physical Science Basis. Contribution of Working Group I to the Fourth Assessment Report of the Intergovernmental Panel on Climate Change, edited by: Solomon, S., Qin, D., Manning, M., Chen, Z., Marquis, M., Averyt, K. B., Tignor, M., and Miller, H. L., Cambridge University Press, Cambridge, United Kingdom and New York, NY, USA, 2007.

Jacob, D. J., Crawford, J. H., Kleb, M. M., Connors, V. S., Bendura, R. J., Raper, J. L., Sachse, G. W., Gille, J. C., Emmons, L., and Heald, C. L.: Transport and Chemical Evolution over the Pacific (TRACE-P) aircraft mission: Design, execution, and first results, J. Geophys. Res.-Atmos., 108(D20), 9000, doi:9010.1029/2002JD003276, 2003.

Jaffe, D., Anderson, T., Covert, D., Kotchenruther, R., Trost, B., Danielson, J., Simpson, W., Berntsen, T., Karlsdottir, S., and Blake, D.: Transport of Asian air pollution to North America, Geophys. Res. Lett., 26, 711-714, 1999.

Jayne, J. T., Leard, D. C., Zhang, X., Davidovits, P., Smith, K. A., Kolb, C. E., and Worsnop, D. R.: Development of an aerosol mass spectrometer for size and composition analysis of submicron particles, Aerosol Sci. Tech., 33, 49-70, 2000.

Jimenez, J. L., Jayne, J. T., Shi, Q., Kolb, C. E., Worsnop, D. R., Yourshaw, I., Seinfeld, J. H., Flagan, R. C., Zhang, X., Smith, K. A., Morris, J. W., and Davidovits, P.: Ambient aerosol sampling with an Aerosol Mass Spectrometer, J. Geophys. Res.-Atmos., 108, 8425, doi:8410:1029/2001JD001213, 2003.

Khlystov, A., Zhang, Q., Jimenez, J., Stanier, C., Pandis, S., Canagaratna, M., Fine, P., Misra, C., and Sioutas, C.: In-situ concentration of semi-volatile aerosol using water-condensation technology, J. Aerosol Sci., 36, 866-880, 2005.

Kleinman, L. I., Daum, P. H., Lee, Y., Senum, G. I., Springston, S. R., Wang, J., Berkowitz, C., Hubbe, J., Zaveri, R. A., and Brechtel, F. J.: Aircraft observations of aerosol composition and ageing in New England and Mid-Atlantic States during the summer 2002 New England Air Quality Study field campaign, J. Geophys. Res., 112, D09310, doi:09310.01029/02006JD007786, 2007.

Leaitch, W. R., Macdonald, A. M., Anlauf, K. G., Liu, P. S. K., Toom-Sauntry, D., Li, S.-M., Liggio, J., Hayden, K., Wasey,
M. A., Russell, L. M., Takahama, S., Liu, S., van Donkelaar, A., Duck, T., Martin, R. V., Zhang, Q., Sun, Y., McKendry, I., Shantz, N. C., and Cubison, M.: Evidence for Asian dust effects from aerosol plume measurements during INTEX-B 2006 near Whistler, BC, Atmos. Chem. Phys. Discuss., 8, 18531-18589, 2008, http://www.atmos-chem-phys-discuss.net/8/18531/2008/.

Liang, Q., Jaeglé, L., Jaffe, D. A., Weiss-Penzias, P., Heckman, A., and Snow, J. A.: Long-range transport of Asian pollution to the northeast Pacific: Seasonal variations and transport pathways of carbon monoxide, J. Geophys. Res.-Atmos., 109, D23S07, doi:10.1029/2003JD004402, 2004.

Liu, B. Y. H., Ziemman, P. J., Kittelson, D. B., and McMurry, P. H.: Generating particle beams of controlled dimensions and divergence: II. Experimental evaluation of particle motion in aerodynamic lenses and nozzle expansions, Aerosol Sci. Tech., 22, 314-324, 1995.

Liu, P. S. K., Deng, R., Smith, K. A., Williams, L. R., Jayne, J. T., Canagaratna, M. R., Moore, K., Onasch, T. B., Worsnop, D. R., and Deshler, T.: Transmission efficiency of an aerodynamic focusing lens system: Comparison of model calculations and laboratory measurements for the Aerodyne Aerosol Mass Spectrometer, Aerosol Sci. Tech., 41, 721-733, 2007.

Matthew, B. M., Middlebrook, A. M., and Onasch, T. B.: Collection efficiencie in an Aerodyne Aerosol Mass Spectrometer as a function of particle phase for laboratory generated aerosols, Aerosol Sci. Tech., 42, 884-898, 2008.

McKendry, I. G., Macdonald, A. M., Leaitch, W. R., van Donkelaar, A., Zhang, Q., Duck, T., and Martin, R. V.: Trans-Pacific dust events observed at Whistler, British Columbia during INTEXB, Atmos. Chem. Phys., 8, 6297-6307, 2008, http://www.atmoschem-phys.net/8/6297/2008/.

Peltier, R. E., Hecobian, A. H., Weber, R. J., Stohl, A., Atlas, E. L., Riemer, D. D., Blake, D. R., Apel, E., Campos, T., and Karl, T.: Investigating the sources and atmospheric processing of fine particles from Asia and the Northwestern United States measured during INTEX B, Atmos. Chem. Phys., 8, 1835-1853, 2008, http://www.atmos-chem-phys.net/8/1835/2008/.

Salcedo, D., Onasch, T. B., Dzepina, K., Canagaratna, M. R., Zhang, Q., Huffman, J. A., DeCarlo, P. F., Jayne, J. T., Mortimer, P., Worsnop, D. R., Kolb, C. E., Johnson, K. S., Zuberi, B., Marr, L. C., Volkamer, R., Molina, L. T., Molina, M. J., Cardenas, B., Bernabé, R. M., Márquez, C., Gaffney, J. S., Marley, N. A., Laskin, A., Shutthanandan, V., Xie, Y., Brune, W., Lesher, R., Shirley, T., and Jimenez, J. L.: Characterization of ambient aerosols in Mexico City during the MCMA-2003 campaign with Aerosol Mass Spectrometry: results from the CENICA Supersite, Atmos. Chem. Phys., 6, 925-946, 2006, http://www.atmoschem-phys.net/6/925/2006/.

Salcedo, D., Onasch, T. B., Canagaratna, M. R., Dzepina, K., Huffman, J. A., Jayne, J. T., Worsnop, D. R., Kolb, C. E., Weimer, S., Drewnick, F., Allan, J. D., Delia, A. E., and Jimenez, J. L.: Technical Note: Use of a beam width probe in an Aerosol Mass Spectrometer to monitor particle collection efficiency in the field, Atmos. Chem. Phys., 7, 549-556, 2007, http://www.atmos-chemphys.net/7/549/2007/.

Seinfeld, J. H. and Pandis, S. N.: Atmospheric chemistry and physics: from air pollution to climate change, Wiley, John \& Sons, Incorporated, New York, USA, 1203 pp., 2006.

Shilling, J. E., Chen, Q., King, S. M., Rosenoern, T., Kroll, J. 
H., Worsnop, D. R., DeCarlo, P. F., Aiken, A. C., Sueper, D., Jimenez, J. L., and Martin, S. T.: Loading-dependent elemental composition of a-pinene SOA particles, Atmos. Chem. Phys., 9, 771-782, 2009, http://www.atmos-chem-phys.net/9/771/2009/.

Singh, H. B., Brune, W. H., Crawford, J. H., Fuelberg, H., and Jacob, D. J.: The Intercontinental Chemical Transport Experiment - Phase B (INTEX-B): An update, online available at: http://cloud1.arc.nasa.gov/docs/intex-na/INTEX-B_White_ Paper.pdf, 2006.

Singh, H. B., Brune, W. H., Crawford, J. H., Flocke, F., and Jacob, D. J.: Chemistry and transport of pollution over the Gulf of Mexico and the Pacific: spring 2006 INTEX-B campaign overview and first results, Atmos. Chem. Phys., 9, 2301-2318, 2009, http://www.atmos-chem-phys.net/9/2301/2009/.

Streets, D. G. and Waldhoff, S. T.: Present and future emissions of air pollutants in China: $\mathrm{SO}_{2}, \mathrm{NO}_{\mathrm{x}}$, and $\mathrm{CO}$, Atmos. Environ., 34, 363-374, 2000.

Streets, D. G., Bond, T. C., Carmichael, G. R., Fernandes, S. D., Fu, Q., He, D., Klimont, Z., Nelson, S. M., Tsai, N. Y., and Wang, M. Q.: An inventory of gaseous and primary aerosol emissions in Asia in the year 2000, J. Geophys. Res.-Atmos., 108(D21), 8809, doi:8810.1029/2002JD003093, 2003.

Sun, Y. and Zhang, Q.: Characterization of water-soluble organic nitrogen in fog/cloud waters using an Aerodyne High Resolution Time-of-Flight Aerosol Mass Spectrometer, Environ. Sci. Technol., submitted, 2009.

Takami, A., Miyoshia, T., Shimonob, A., Kaneyasuc, N., Katod, S., Kajiid, Y., and Hatakeyamaa, S.: Transport of anthropogenic aerosols from Asia and subsequent chemical transformation, J. Geophys. Res., 112, D22S31, doi:10.1029/2006JD008120, 2007.

Takegawa, N., Miyazaki, Y., Kondo, Y., Komazaki, Y., Miyakawa, T., Jimenez, J. L., Jayne, J. T., Worsnop, D. R., Allan, J. D., and Weber, R. J.: Characterization of an Aerodyne Aerosol Mass Spectrometer (AMS): Intercomparison with other aerosol Instruments, Aerosol Sci. Tech., 39, 760-770, 2005.

Takegawa, N., Miyakawa, T., Kawamura, K., and Kondo, Y.: Contribution of selected dicarboxylic and oxocarboxylic acids in ambient aerosol to the $\mathrm{m} / \mathrm{z} 44$ signal of an Aerodyne Aerosol Mass Spectrometer, Aerosol Sci. Tech., 41, 418-437, 2007.

Turpin, B. J. and Lim, H. J.: Species contributions to PM $_{2.5}$ mass concentrations: Revisiting common assumptions for estimating organic mass, Aerosol Sci. Tech., 35, 602-610, 2001.

van Aardenne, J. A., Carmichael, G. R., LevyIi, H., Streets, D., and Hordijk, L.: Anthropogenic $\mathrm{NO}_{\mathrm{x}}$ emissions in Asia in the period 1990-2020, Atmos. Environ., 33, 633-646, 1999.

van Donkelaar, A., Martin, R. V., Leaitch, W. R., Macdonald, A. M., Walker, T. W., Streets, D. G., Zhang, Q., Dunlea, E. J., Jimenez, J. L., Dibb, J. E., Huey, L. G., Weber, R., and Andreae, M. O.: Analysis of aircraft and satellite measurements from the Intercontinental Chemical Transport Experiment (INTEX-B) to quantify long-range transport of East Asian sulfur to Canada, Atmos. Chem. Phys., 8, 2999-3014, 2008, http://www.atmoschem-phys.net/8/2999/2008/.
Wolfe, G. M., Thornton, J. A., McNeill, V. F., Jaffe, D. A., Reidmiller, D., Chand, D., Smith, J., Swartzendruber, P., Flocke, F., and Zheng, W.: Influence of trans-Pacific pollution transport on acyl peroxy nitrate abundances and speciation at Mount Bachelor Observatory during INTEX-B, Atmos. Chem. Phys., 7, 53095325, 2007, http://www.atmos-chem-phys.net/7/5309/2007/.

Yienger, J. J.: The episodic nature of air pollution transport from Asia to North America, J. Geophys. Res., 105, 26931-26946, 2000.

Zhang, Q. and Anastasio, C.: Chemistry of fog waters in California's Central Valley - Part 3: concentrations and speciation of organic and inorganic nitrogen, Atmos. Environ., 35, 5629-5643, 2001.

Zhang, Q., Anastasio, C., and Jimenez-Cruz, M.: Watersoluble organic nitrogen in atmospheric fine particles $\left(\mathrm{PM}_{2.5}\right)$ from Northern California, J. Geophys. Res., 107(D11), 4112, doi:4110.1029/2001JD000870, 2002.

Zhang, Q., Alfarra, M. R., Worsnop, D. R., Allan, J. D., Coe, H., Canagaratna, M. R., and Jimenez, J. L.: Deconvolution and quantification of hydrocarbon-like and oxygenated organic aerosols based on aerosol mass spectrometry, Environ. Sci. Technol., 39, 4938-4952, doi:4910.1021/es0485681, 2005a.

Zhang, Q., Canagaratna, M. C., Jayne, J. T., Worsnop, D. R., and Jimenez, J. L.: Time and size-resolved chemical composition of submicron particles in Pittsburgh - Implications for aerosol sources and processes, J. Geophys. Res., 110, D07S09, doi:10.1029/2004JD004649, 2005b.

Zhang, Q., Worsnop, D. R., Canagaratna, M. R., and Jimenez, J. L.: Hydrocarbon-like and oxygenated organic aerosols in Pittsburgh: insights into sources and processes of organic aerosols, Atmos. Chem. Phys., 5, 3289-3311, 2005c,

http://www.atmos-chem-phys.net/5/3289/2005/.

Zhang, Q., Jimenez, J. L., Canagaratna, M. R., Allan, J. D., Coe, H., Ulbrich, I., Alfarra, M. R., Takami, A., Middlebrook, A. M., Sun, Y. L., Dzepina, K., Dunlea, E., Docherty, K., DeCarlo, P. F., Salcedo, D., Onasch, T., Jayne, J. T., Miyoshi, T., Shimono, A., Hatakeyama, S., Takegawa, N., Kondo, Y., Schneider, J., Drewnick, F., Weimer, S., Demerjian, K., Williams, P., Bower, K., Bahreini, R., Cottrell, L., Griffin, R. J., Rautiainen, J., Sun, J. Y., Zhang, Y. M., and Worsnop, D. R.: Ubiquity and dominance of oxygenated species in organic aerosols in anthropogenicallyinfluenced northern hemisphere mid-latitudes, Geophys. Res. Lett., 34, L13801, doi:13810.11029/12007GL029979, 2007a.

Zhang, Q., Jimenez, J. L., Worsnop, D. R., and Canagaratna, M.: A case study of urban particle acidity and its effect on secondary organic aerosol, Environ. Sci. Technol., 41, 3213-3219, $2007 \mathrm{~b}$. 